American University Washington College of Law

Digital Commons @ American University Washington College of

Law

Articles in Law Reviews \& Other Academic Journals

Scholarship \& Research

2016

Can Parallel Lines Ever Meet? The Strange Case of the International Standards on Sovereign Debt and Business and Human Rights

Daniel D. Bradlow

Follow this and additional works at: https://digitalcommons.wcl.american.edu/facsch_lawrev

Part of the Banking and Finance Law Commons, Bankruptcy Law Commons, Human Rights Law Commons, International Law Commons, and the Law and Economics Commons 


\title{
Can Parallel Lines Ever Meet? The Strange Case of the International Standards on Sovereign Debt and Business and Human Rights
}

\author{
Daniel D. Bradlow*
}

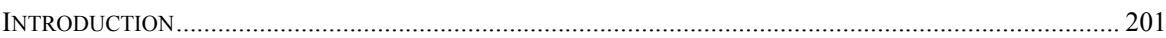

I. SOME RELEVANT CONSIDERATIONS REGARDING THE SODR PROCESS .................................................. 205

II. INTERNATIONAL NORMS AND STANDARDS APPLICABLE TO SOVEREIGN DEBT WORKOUTS ..............2 211

III. INTERNATIONAL NORMS AND STANDARDS DEALING WITH BusinesS AND HUMAN RIGHTS .......... 216

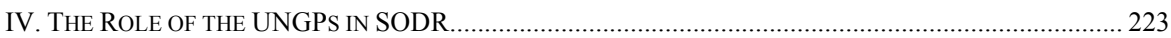

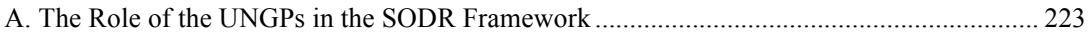

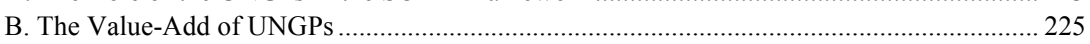

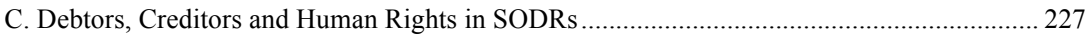

1. The First Pillar: Duties of the Sovereign Debtor ........................................................... 227

2. The Second Pillar: The Responsibility of Financial Institutions ............................... 230

3. The Third Pillar: Access to Remedies ………….................................................... 232
\end{abstract}

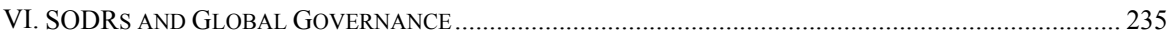

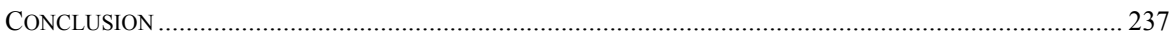

\section{INTRODUCTION}

Sovereigns have a long history of defaulting on their debts. ${ }^{1}$ Despite the bitter lessons learned through this history, the international community has not yet developed an effective method for dealing with these events. There is not a single forum or mechanism that is mandated to help the debtor and all its creditors develop a comprehensive plan for resolving its debt crisis. Instead the debtor is usually required to negotiate in different forums with each of its different categories of creditors. There are no formal mechanisms of coordination between these different sets of negotiations even though their individual outcomes are affected by what happens in the other negotiations as each group of creditors seeks to ensure that it is not being treated unfairly by

* SARCHI Professor of International Development Law and African Economic Relations, Centre for Human Rights, University of Pretoria, and Professor Emeritus, American University Washington College of Law. Email: danny.bradlow@up.ac.za. The author thanks Motoko Aizawa, Juan Pablo Bohoslavsky, Lee Buchheit, Matthias Goldmann and David Kinley for their thought-provoking comments on an earlier draft of the paper, prepared for the 2016 Society of International Economic Law conference. Needless to say, they are not responsible for the conclusions that the author has drawn from their comments. The author also thanks Nthope Mapefane for her research assistance.

1. CARMEn M. ReInhart and KenNeth Rogoff, This time is DifFerent: eight CENTURIES OF FINANCIAL FOLLY (2009). 
the debtor. As a result, each sovereign's debt restructuring process is likely to be conflict ridden, inefficient and to have a high probability of resulting in a sub-optimal outcome. In fact, the risk of sub-optimal outcomes has increased as financial markets have become larger and more globalized so that sovereign debtors - at least those with access to financial markets - are able to borrow from a broader range of creditors.

One consequence is that sovereign debt restructurings (SODRs), as can be seen from the cases of Greece ${ }^{2}$ and Argentina, ${ }^{3}$ are difficult, often traumatic, experiences for the sovereign debtors and their populations and frustrating and potentially costly for their creditors. It is invariably the case that in a SODR, the sovereign, because it either has lost access to financing or can only obtain it on more expensive terms, will be forced to reduce its expenditures in order to try and meet its existing debt obligations. This means that it is entirely foreseeable that the sovereign's debt problems will have a range of adverse economic, social and political impacts ${ }^{4}$ in the debtor country. It is also likely that the creditors will suffer financial losses due to the costs associated with the renegotiation of their credit transactions with a sovereign borrower in difficulty. There may also be losses associated with the delayed or reduced interest payments, and possibly reduced principle repayments that result from the SODR.

The SODR therefore carries a high risk of having adverse human rights impacts on at least some of the stakeholders in the SODR. These impacts can include less access to health services, education services and other social services as funding for these services are reduced; loss of access to justice as spending on police, courts and legal services are cut; and job losses. ${ }^{5}$ On the creditor side, depending on the size of the loss and the identity of the ultimate holders of the debt, the SODR can result in job losses for the creditor's employees or the loss of savings and income for pensioners and other bondholders of modest means. ${ }^{6}$ The net effect of these potential impacts is that

2. Truth Committee on Greek Public Debt: Preliminary Report (June 18, 2015), available at http://cadtm.org/Preliminary-Report-of-the-Truth; Margot E. Salomon \& Olivier De Schutter, Economic Policy Conditionality, Socio-Economic Rights and International Legal Responsibility: The Case of Greece 2010-2015 (Legal Brief prepared for the Special Committee of the Hellenic Parliament on the audit of the Greek Debt, 2015); U.N. Human Rights Council, Report of the Independent Expert on the effects of foreign debt and other related international financial obligations of States on the full enjoyment of all human rights, particularly economic, social and cultural rights on his mission to Greece, A/HRC/31/60/Add.2 (Feb 29, 2016)

3. Brad Setser \& Anna Gelpern, Pathways Through Financial Crisis: Argentina, 1 GloBAL GOVERNANCE: A REVIEW OF MULTILATERALISM AND INTERNATIONAL ORGANIZATIONS 465 (2006).

4. Sovereign debt crises also can have substantial adverse environmental and social effects. However since the focus of this article is on the human rights impacts of these crises, the environmental consequences will not be discussed. It should be noted, however, that these environmental consequences can have human rights implications and to this extent fall within the ambit of this article.

5. Truth Committee on Greek Public Debt, supra note 2; The Inspection Panel Report on ARGENTINA-SEGBA V Power Distribution Project (Loan No. 2854 - AR), available at http://siteresources.worldbank.org/EXTINSPECTIONPANEL/Resources/ParaguayEligibilityReportwan nexes.pdf; ECtHR: Koufaki and Adedy v Greece, Appl. Nos. 57665/12 57657/12, available at http://hudoc.echr.coe.int/app/conversion/pdf/?library=ECHR\&id=002-7627\&filename=002-7627.pdf; Abaclat et al. v. Argentine Republic, ICSID case number ARB/07/5, Decision on Jurisdiction and Admissibility (Aug 4, 2011), available at http://www.italaw.com/sites/default/files/casedocuments/ita0236.pdf.

6. Jessica Beess und Chrostin, Sovereign Debt Restructuring and Mass Claims Arbitration 
SODRs will involve a struggle between the debtor and its creditors and amongst the different stakeholders on both the creditor and debtor sides to avoid having to bear more than their fair (as they define it) share of the financial losses and to mitigate the economic, financial, social, human rights and political consequences of the SODR.

Given these high stakes, it is not surprising that efforts have been made over the past 70 years to improve the process. One recent manifestation of this effort has been the promulgation of a number of international norms and standards that either explicitly or implicitly are applicable to SODRs. These include norms and standards that are expressly designed to improve the efficiency of the sovereign debt negotiation and renegotiation processes such as the Institute for International Finance's (IIF), ${ }^{7}$ "Principles for Stable Capital Flows and Fair Debt Restructuring in Emerging Markets", and the United Nations Conference on Trade and Development's (UNCTAD) "Principles on Responsible Sovereign Lending and Borrowing", and "Sovereign Debt Workouts: Roadmap and Guide" (Roadmap) ${ }^{9}$ and the UN's Guiding Principles on Foreign Debt and Human Rights. ${ }^{10}$

Interestingly, the documents dealing with the SODR process all recognize that SODRs have substantial social and political effects in addition to their financial and economic consequences. In fact, they all appear to accept that the parties to the SODR will need to take these impacts into account in arranging a sustainable SODR. However, they do not provide detailed guidance to the parties on how they should deal with these social and political impacts in negotiating and agreeing on a sustainable SODR. Except for the UN Guiding Principles on Foreign Debt and Human Rights and the UNCTAD Roadmap, which does so briefly, they do not discuss the human rights impacts of SODRs. This is surprising given the norms and standards that companies and states have developed for dealing with the social responsibilities, including in regard to human rights, of businesses. These norms and standards include the UN's Guiding Principles on Business and Human Rights (UNGPs), ${ }^{11}$ the Global

before the ICSID: The Abaclat Case, 53 HARV. InT'L LJ 505 (2012); Stacie I. Strong, Rogue Debtors and Unanticipated Risk, 35 U. PA. J. INT'L L. 1139 (2013).

7. Institute of International Finance, Principles for Stable Capital Flows and Fair Debt Restructuring in Emerging Markets (March 31, 2005), available at https://www.iif.com/topics/principles-stable-capital-flows-and-fair-debt-restructuring; Institute of International Finance, PCG Report on Implementation of the Principles (2015), available at https://www.iif.com/news/capital-markets-and-emerging-markets-policy/2013-pcg-report-implementationprinciples. See infra notes 34-38 and accompanying text for discussion of these Principles.

8. UNCTAD, Principles on Promoting Responsible Sovereign Lending and Borrowing, UNCTAD/GDS/DDF/2012/Misc.1 (Jan 10, 2012), available at http://unctad.org/en/PublicationsLibrary/gdsddf2012misc1 en.pdf. See infra notes 39-50 and accompanying text for discussion of these Principles.

9. UNCTAD, Sovereign Debt Workouts: Going Forward. Roadmap and Guide (2015), available at $\mathrm{http}: / /$ unctad.org/en/PublicationsLibrary/gdsddf2015misc1_en.pdf; see infra notes 51-56 and accompanying text for discussion of the Roadmap.

10. Annex to Resolution 20/10 of the U.N. Human Rights Council, The Effects of Foreign Debt and Other Related International Financial Obligations of States on the Full Enjoyment of All Human Rights, particularly Economic, Social and Cultural Rights, U.N. Doc. A/HRC/RES/20/10 (July $18,2012)$.

11. United Nations OfFice of the High COMmissioner FOR Human Rights, Guiding PRINCIPLES ON BUSINESS AND HUMAN RIGHTS, U.N. DOC. HR/PUB/11/04, available at http://www.ohchr.org/Documents/Publications/GuidingPrinciplesBusinessHR_EN.pdf. 
Compact, ${ }^{12}$ the OECD Guidelines on Multinational Enterprises ${ }^{13}$ and ISO $26000 .^{14}$

The seeming disconnect between the developments related to the SODR process and to business and human rights is intriguing, particularly because many of the world's most significant financial institutions have publically available human rights policies that, at least prima facie, are applicable to all their business operations and relations. ${ }^{15}$ Moreover, given the scope of their operations, they are likely to be creditors in at least some SODRs. In addition, the human rights implications of SODRs are sufficiently predictable, profound and adverse that one would expect that these institutions, if they take their own human rights policies seriously, would try and ensure that the SODRs in which they participate conform to their own human rights policies and to the international standards dealing with human rights and business, which are often referenced in those policies.

The disconnect between these two developments raises at least two questions. First, should the human rights and business standards be applied to the SODR process. Second, if they should be applied to the SODR process, how should they be applied?

The primary purpose of this article is to answer these two questions. This exercise serves three purposes. First, it will enable us to see if these human rights and business standards can add value to SODRs in the sense of reducing their human rights costs without unduly increasing their financial costs. Second it will provide some additional insight into how easily human rights law can be adapted to financial transactions specifically and to business more generally. Third, this exercise might help us better understand how to plug the gap in global economic governance that allows different actors in global governance to develop international standards on SODR and on business and human rights on parallel tracks that do not seem to communicate with each other.

The consideration of these issues leads to three conclusions. First, SODRs would benefit from the incorporation of business and human rights standards. These standards would help SODRs reach outcomes that produce fewer and/or less severe adverse human rights impacts. This, in turn, should improve the legitimacy of the SODR outcome, thereby facilitating its implementation and enhancing its sustainability to the benefit of all parties to the SODR. Second the application of the UNGPs to SODRs indicates that the subject of business and human rights poses a challenge for human rights law. The reason is that the way in which human rights issues arise in the business context is often different from the way in which they arise in the relationship between the state and its citizens. As a

12. U.N. Global Compact, The Ten Principles of the Global Compact (Jan 31, 1999), available at https://www.unglobalcompact.org/what-is-gc/mission/principles, see infra notes 83-88 and accompanying text for discussion of the Global Compact.

13. OECD, Guidelines for Multinational Enterprises (May 25, 2011), available at http://www.oecd.org/daf/inv/mne/48004323.pdf, see infra note 82 and accompanying text for discussion of these Guidelines.

14. ISO 26000 Guidance to Social Responsibility (Nov 1, 2010), available at https://www.iso.org/obp/ui/\#iso:std:iso:26000:ed-1:v1:en, see infra note 89-91 and accompanying text for discussion of ISO 26000

15. See, infra, notes 100-109 and accompanying text for discussion of the human rights policies of the major international banks. 
result, the jurisprudence on the application of human rights principles in the latter context cannot simply be transposed without adjustments into the former context. However, we do not yet have the knowledge or experience to fully understand the nature and type of adjustments that are needed for this transposition to be effective. Third, the article will conclude that the lack of coordination between the international standards applicable to SODRs and those applicable to the human rights responsibilities of creditors is a symptom of a coordination problem in global economic governance. One consequence of which is an over-emphasis on financial and economic considerations in complex financial transactions like SODRs.

In order to make this case, this article is divided into five sections. The first section will provide a brief overview of the key characteristics of the SODR process that are relevant to understanding the human rights impacts of these transactions. The second section will describe the various international norms and standards applicable to SODRs. The third section will describe the primary international standards applicable to the issue of business and human rights. The fourth section will consider the applicability of the UNGPs to SODRs. The final section is the conclusion.

\section{Some RELEVAnt Considerations REGARDing THE SODR PRocesS}

The purpose of this paper is to focus on how sovereign debtors and financial institutions that extend credit to them currently deal with human rights issues in SODRs. It is not to give a comprehensive overview of SODRs. ${ }^{16}$ In order to place the issue of SODR's human rights impacts in context, the focus of this section is on the planning and negotiating process in SODRs. It will not discuss in any detail the role that international financial institutions like the IMF or bilateral creditors play in the SODR process, ${ }^{17}$ the many financial and economic factors that may influence the ultimate results of the SODR process or the many important contractual issues that can arise in SODRs. ${ }^{18}$

In order to place the points made below in context it is useful to give a brief overview of the current approach to the SODR process. The usual SODR involves a number of different debtor-creditor negotiations. The debtor will negotiate with its official bilateral creditors in the Paris Club, an informal forum, housed within the French Treasury. ${ }^{19}$ It is possible that there may be

16. See generally Sovereign Debt ManAgement (Rosa M. Lastra and Lee C. Buccheit eds., 2014) (providing an overview of the legal and other issues involved in SODRs).

17. It should be noted that the multilateral development banks and bilateral official creditors can be important actors in many SODRs, particularly in the case of low income countries.

18. Steven L. Schwarcz, Sovereign Debt Restructuring: A Bankruptcy Reorganization Approach, 85 CORnell L. REV. 956 (2000); Matthias Goldmann, Human Rights and Sovereign Debt Workouts, in MAKING SOvEREIGN FinANCING AND HuMAN RightS WORK 79 (Juan Pablo Bohoslavsky \& J. Letnar Cernic eds., 2014); Steven L. Schwarcz, Sovereign Debt Restructuring Options: An Analytical Comparison, 2 HARV. Business L. REV. (2012); Francois Gianviti et al., A European Mechanism for Sovereign Debt Crisis Resolution: A Proposal, Bruegel Blueprint Series (2010), available at

content/uploads/imported/publications/101109_BP_as_jpf_jvh_A_European http://bruegel.org/wp-

_mechanism_for_sovereign_debt_crisis_resolution_a_proposal.pdf.

19. The Paris Club, which is informal in the sense that it has no independent legal identity, is a grouping of official creditors who meet with sovereign debtors in difficulty to renegotiate their debts to 
some official creditors who are not part of the Paris Club and with whom the debtor will need to negotiate separately.

The sovereign debtor will negotiate with its commercial creditors in one or more forums. ${ }^{20}$ For example, it may negotiate with its bond holders in one forum, often informally referred to as "the London Club", its commercial bank creditors in a separate forum and with companies to whom it has outstanding debts on goods and services that it has purchased or to whom it owes payments for items such as royalties or dividends in another forum, in which the various companies either participate collectively or in sub-groups or it may negotiate with them individually. The creditors in these different forums are likely to seek to ensure, at least to the extent of their bargaining power, that the debtor treats them all more or less equivalently. ${ }^{21}$ It is also possible that the agreements reached in some of these negotiating forums are not comprehensive in the sense that not all creditors eligible to participate in the particular forum sign the agreement reached in that forum. In this case, the debtor can be forced into a second set of negotiations, or, for example as happened in Argentina, ${ }^{22}$ into litigation with these disgruntled creditors. In most circumstances the multilateral official creditors of the debtor, such as the multilateral development banks or the International Monetary Fund, do not participate as creditors in the SODR. ${ }^{23}$ The reason for this is that by custom they have preferred creditor status and so their debts are not included in the SODR. ${ }^{24}$ Their contribution to the SODR process typically is to provide financial and technical support to the sovereign debtor during the SODR.

these official creditors. The creditors and the debtor agree, in an Agreed Minute, on the general terms on which all qualifying official debts shall be renegotiated. Each official creditor then concludes its own bilateral agreement with the sovereign debtor based on the terms in the Agreed Minute. There are currently 20 countries whose official financial agencies, such as their export credit agencies and their aid agencies, participate as permanent participants in the Paris Club. Other countries and their agencies can participate on an ad hoc basis in the negotiations for a particular debtor country. See generally http://www.clubdeparis.org; Martin A. Weiss, Cong. ReSearch SerV., RS21482, The Paris Club AND INTERNATIONAL DEBT RELIEF (2004); THOMAS CALLAGHY, INNOVATION IN THE SOVEREIGN DEBT REGIME: From THE PARIS ClUB TO ENHANCED HIPC AND BEYOND (2004).

20. Raman Uppal \& Cynthia Van Hulle, Sovereign Debt and the London Club: A Precommitment Device for Limiting Punishment for Default, 21 Journal of BANKING \& FINANCE 741 (1997); Giovanni Vitale, Multilateral Sovereign Debt Restructuring: the Paris Club and the London Club, in Crisis? What CRISIS? ORderly WORKOUT FORS SOVEREIGN DEBTORS 122 (Barry Eichengreen \& Richard Portes eds., 1995); Udaibir Das, Michael G. Papaioannou \& Christoph Trebesch, Sovereign Debt Restructurings 1950-2010: Literature Survey, Data, and Stylized Facts (International Monetary Fund Working Paper WP/12/203, 2012).

21. Sovereign Debt Management, supra note 16; Lee C. Buchheit \& G. Mitu Gulati, Sovereign Bonds and the Collective Will, 51 EMORY L. J. 1317 (2002); Lee C. Buchheit \& Jeremiah S. Pam, The Pari Passu Clause in Sovereign Debt Instruments, 53 EMORY L. J. 869 (2004); Gregory Makoff \& Robert Kahn, Sovereign Bond Reform - Implementing the New ICMA Pari Passu and Collective Action Clause (CIGI Papers, 2015), available at https://www.cigionline.org/sites/default/files/cigi_paper_no_56.pdf.

22. NML Capital, Ltd. v. Argentina, No. 08 Civ 6978 (TPG) (S.D.N.Y. Feb. 23, 2012) (granting preliminary injunction); NML Capital, Ltd. V. Argentina, 699 F.3d 246, 264 (2d Cir. 2012); NML Capital, Ltd. v. Argentina, No. 08 Civ 6978 (TPG), 2012 U.S. Dist. LEXIS 167272 (S.D.N.Y. Nov. 21, 2012); Elliott Associates, L.P. v. Republic of Peru 12 F. Supp. 2d 328 (S.D.N.Y. 1998).

23. Emine Boz, Sovereign Default, Private Sector Creditors, and the IFIs, 83 J. OF INT'L ECONOMICS 70 (2011). It should be noted that there have been occasions, for example during the HIPC initiative, in which these institutions did agree to participate as creditors and to reduce the debt owed to them by their sovereign borrowers.

24. William Wilson Bratton \& G. Mitu Gulati, Sovereign Debt Restructuring and the Best Interest of Creditors, 57 VANDERBILT L. REV. 1 (2010). 
There are a few points that need to be highlighted in order to understand the treatment of human rights issues in the SODR process:

First, the creditors maintain that the sovereign freely assumed its debt obligations and promised to meet all its promises in regard to repayment. The fact that it is no longer living up to its promises, particularly when it has financial resources available, ${ }^{25}$ is a choice for which it and its citizens must accept the consequences. From the creditors' position, this is not unfair because the debtor broke its promise to repay and there is no reason why the creditor and its stakeholders should have to bear the cost of this breach of its obligations. On the other hand, the citizens of the debtor country may contend that they were not expressly consulted by their government about the debts and the risks associated with taking on those debts. Consequently, they may not understand why they, rather than the creditors who did assume the risks associated with making the loan, should be expected to make sacrifices in order to meet the demands of the creditors.

Second, as indicated above, there is no formal independent mechanism that sovereign borrowers and their financial institution creditors can utilize during a SODR. This means that there is no third party entity that can help the sovereign debtor and the creditors reach a mutually acceptable agreement and then monitor and enforce the SODR.$^{26}$ Instead, the parties have to form and manage their own negotiating forums. Thus, the overall outcome of the negotiations in each of these forums and of the overall SODR is likely to depend on the relative bargaining power of the parties and their need to reach an agreement without any offsetting third party to try and ensure some balance in the negotiations. The uncertainty resulting from the sovereign's inability to fully service its debts gives both parties an incentive to reach agreement as quickly as possible. However, normally the sovereign has a greater need to resolve its situation than its creditors. This reality tilts the balance of bargaining power, in most SODRs, in favor of the creditors. ${ }^{27}$

25. In most cases the sovereign debtor will have some financial resources, although not enough to meet all its financial commitments. Consequently, the creditors will contend that the decision not to meet its debt obligation is a choice in the sense that it is deciding to allocate its funds for purposes other than debt servicing.

26. The international community has periodically attempted to establish such a third party mechanism. See generally, Martin Guzman, José A. Ocampo \& Joseph E. Stiglitz, Creating a Framework for Sovereign Debt Restructuring that Works, in TOO LiTTLE, TOO LATE: THE QUEST TO RESOLVE SOVEREIGN DEBT CRISES (Martin Guzman et al. eds., 2016). There have been two such efforts this century. See Eric Helleiner, The Mystery of the Missing Sovereign Debt Restructuring Mechanism, 27 Contributions to Political ECONOMY 91-113 (2008). In the early 2000s, the International Monetary Fund (IMF) explored the feasibility of creating a sovereign debt restructuring mechanism and concluded that it was not possible. See Anne O. Kreuger, A New Approach to Sovereign Debt Restructuring (IMF, 2002), avaiable at $\mathrm{http} / / \mathrm{www} . \mathrm{imf}$. org/external/pubs/ft/exrp/sdrm/eng/sdrm.pdf. More recently, the United Nations General Assembly passed a resolution calling for the creation of such a mechanism. This effort has resulted in a set of U.N. principles to guide the structuring of such a mechanism and a working group to consider its creation but not in an actual agreement to establish such a mechanism. See G.A. Res. 69/319 (Sept. 29, 2015), available at http://www.un.org/en/ga/search/view_doc.asp?symbol=A/RES/69/319.

27. The IMF has indicated that in some cases it will be willing to lend into arrears, which may restore some balance to the distribution of bargaining power. See generally, IMF, Policy on Lending into Arrears to Private Creditors (June 14, 1999), available at https://www.imf.org/external/pubs/ft/privcred/lending.pdf; IMF, Fund Policy on Lending into Arrears to Private Creditors-Further Consideration of the Good Faith Criterion (July 30, 2002), available at 
In light of the failure to reach agreement on the establishment of a formal independent sovereign debt restructuring mechanism, ${ }^{28}$ the international community has used two different approaches, which are not mutually exclusive, to try and improve the SODR process. One strategy has been to adjust the contractual arrangements between debtors and creditors so that they provide for more efficient SODRs. The primary fruits of these efforts are the incorporation of collective action clauses and revised pari passu clauses in sovereign debt financing agreements. ${ }^{29}$ The collective action clauses make it harder for small groups of recalcitrant creditors to block SODR agreements between the debtors and creditors. The revised pari passu clauses are intended to reduce the chances for success of claims like those made by the hold out creditors in the Argentinian litigation. ${ }^{30}$ The second approach has been to develop standards that are designed to establish more efficient ground rules for the negotiation and renegotiation of sovereign debt. This second approach is discussed in detail in the next section of this paper.

Third, the balance of bargaining power is also affected by the fact that both parties understand that the borrower's situation is likely to continue deteriorating until an agreement is reached. Consequently, delay in reaching an agreement may increase the potential costs of the SODR to both creditors and debtor. This places both parties under time pressure and it inevitably means that any requirement that the parties collect new data in order to gain new insights and a better understanding of the borrower's situation has a cost for all stakeholders in the SODR. It thus creates a disincentive for the parties to add new steps to the SODR process, even if they do result in a more informed SODR outcome.

Fourth, by definition, in a SODR, the sovereign debtor does not have enough financing to meet all its financial commitments. ${ }^{31}$ This does not necessarily mean that the sovereign has no foreign exchange. In fact, in most cases the sovereign will have access to some financing but probably not enough to meet all its commitments to its citizens and its creditors. The result is that it

https://www.imf.org/external/pubs/ft/privcred/073002.pdf; IMF, Sovereign Debt Restructuring - recent developments and implications for the fund's legal and policy framework (Apr 26, 2013), available at http://www.imf.org/external/np/pp/eng/2013/042613.pdf.

28. See supra note 26.

29. Lee C. Buchheit et al., supra note 21; Skylar Brooks \& Domenico Lombardi, Governing Sovereign Debt Restructuring Through Regulatory Standards, 6 JOURNAL OF GLOBALIZATION AND DEVELOPMENT 287 (2016); Roberto Blanco, Simon Brennan \& Ian W. Marsh, An Empirical Analysis of the Dynamic Relation between Investment Grade Bonds and Credit Default Swaps, 60 THE JOURNAL OF FINANCE 2255 (2005); Lee C. Buchheit \& Jeremiah S. Pam, supra note 21.

30. See supra note 22.

31. The tight constraints within which the sovereign has to make these choices are loosened to the extent that it can obtain foreign exchange from international financial institutions such as the IMF and the MDBs. However, these resources come at a price. The price is paid partially in terms of the conditionalities that the IFIs attach to their funding, which, in turn, impact on the sovereign's choices in how to allocate its foreign exchange. Once again these choices have social and human rights impacts. The issue of the IFI's human rights responsibilities is outside the scope of this paper but see, e.g., Daniel D. Bradlow, World Bank, the IMF, and Human Rights 6 TRANSNATIONAL LAW AND CONTEMPORARY Problems 47 (1996); MaC Darrow, Between Light and Shadow: THE World BanK, the INTERNATIONAL MONETARY Fund AND INTERNATIONAL HuMAN Rights LAW (2003). See generally, InTERNATIONAL FinANCial InSTITUTIONS \& InTERNATIONAL LAW (Daniel D. Bradlow \& David B. Hunter eds., 2010). 
must make choices about how to allocate its available funds. These choices inevitably have human rights impacts that raise challenges for the sovereign's own human rights obligations. To the extent that the choices are influenced by negotiations with the creditors, these choices will also have implications for the human rights responsibilities of the commercial creditors.

Historically, all the parties to the SODR process have maintained, at least in a formal sense, that the decision of how to allocate the sovereign's limited financial resources is the prerogative of the sovereign debtor. This decision is perceived to relate to its responsibilities as a sovereign and it is a decision for which it is accountable to its citizens. The commercial creditors should respect the decision regardless of whether they think it is a wise decision or is consistent with the human rights obligations of the borrower. ${ }^{32}$ This follows from the creditors' obligation to obey all the applicable law in the debtor state and to respect its sovereignty. Within the constraints of these obligations, the creditors are free to negotiate any SODR with the borrower that they deem acceptable.

Given the realities of the balance of bargaining power between the parties in an SODR, it is not tenable to maintain that this decision is purely a sovereign prerogative. The outcome of the debt renegotiation is a mutually bargained and agreed arrangement, in which both parties, in fact, have little choice other than to reach some sort of agreement. Moreover since the choice of how the sovereign allocates its limited foreign exchange has implications for the success of the SODR, it is not credible to maintain that the creditors merely passively accept the decision of the debtor and try to negotiate for the best possible deal within the constraints of this sovereign decision. Their negotiating strategy inevitably and intentionally influences the sovereign's decision on how it allocates its limited foreign exchange. This suggests that the responsibilities for the human rights impacts of the agreement should be attributed to both parties. It is not reasonable for the financial institutions to place all the responsibility for the human rights impacts of the agreement on the borrower. This is particularly the case when the creditors are able to block the sovereign debtor's access to international financial markets until an agreement is reached.

Fifth, historically the commercial creditors have used their bargaining power to exclude certain concerns of the sovereign from the ambit of the negotiations. For example, the creditors might not accept as relevant to their SODR negotiations claims by the sovereign that its responsibilities to provide their citizens with adequate food and medicine imports should have a higher priority than payment of commercial creditors. ${ }^{33}$ This view, as long as it can be enforced by the creditors through their bargaining power, can result in the creditors demanding and receiving a larger share of the available foreign exchange than would have been the case if these other issues had been treated

32. See generally, Daniel D. Bradlow, Differing Conceptions of Development and the Content of International Development Law, 21 SOUTH AFRICAN JOURNAL ON HUMAN RIGHTS 1 (2005); Robert McCorquodale \& Penelope Simons, Responsibility Beyond Borders: State Responsibility for Extraterritorial Violations by Corporations of International Human Rights Law, 70 THE MODERN LAW REVIEW 598 (2007).

33. Julius Nyerere, "Should we really let our people starve so we can pay our debts?" THE GUARDIAN, Mar. 21, 1985. 
as valid considerations within the context of the SODR negotiations. The result can be to exacerbate the adverse human rights impacts of the SODR agreement.

Sixth, the creditors often argue that, while they understand that the proposed SODR outcome will cause the sovereign and its citizens pain, the situation would be worse if the sovereign does not pay them what they are asking. The reason is that, in the absence of the proposed agreement, the sovereign risks being frozen out of international financial markets for an unduly long period of time. Ultimately, they contend, this will cause the pain of the SODR to last for a longer period and to affect more people, than would otherwise have been the case. In short, they argue, at least by implication, that although the deal they are offering is painful for the sovereign and its subjects it will cause fewer and smaller adverse human rights impacts over time than will the more generous deal the sovereign is demanding.

The validity of the creditors' argument depends on a range of assumptions about how financial markets and the other stakeholders in the SODR will react if the creditors' proposals are adopted. In principle it is possible for the parties to assess the potential consequences of the creditors' proposals and their impacts on the various stakeholders in the SODR. However, it is not easy to do so, particularly when the assessments must be done under time pressure. This means that any ex ante assessments are likely to be based on imperfect and incomplete information.

Seventh, the SODR will be complicated by the fact that there is a bargaining process that takes place among the different stakeholders on the debtor side. In this process, for example, the different stakeholders in the debtor society will bargain with each other and the state over how to allocate the costs of the SODR. The most likely outcome of this process is that the more powerful stakeholders in the debtor state will use their power and influence to minimize the adjustment burden that they have to bear and to shift the burden onto weaker, and usually poorer stakeholders. This increases the likelihood that the SODR will have substantial adverse human rights consequences.

Given the stakes in these internal negotiations, all the domestic stakeholders are likely to use whatever allies they have both within the debtor state and among other stakeholders in the SODR to improve their bargaining positions. The various groups of creditors risk being drawn into this domestic negotiation and, regardless of their responses, having an impact on the outcome of the domestic negotiations and thereby on the overall SODR outcome. This suggests that the historical view that the decision on how to allocate the pain of the SODR decision is purely the prerogative of the sovereign, at best, elevates form over substance. The creditors will inevitably exert influence over these decisions, regardless of how well they may camouflage this reality behind legal formalities.

This raises the question of what consequences should follow from the fact that they are implicated in the decision. Increasingly, the international community is indicating that it expects the commercial creditors to behave responsibly, including in human right terms, in their lending decisions. The international community has developed one set of standards for guiding financial institutions in regard to their conduct in the SODR process and 
another set in regard to their responsibilities for the human rights impacts of their transactions. These two sets of standards are discussed in the next two sections of the paper.

\section{INTERNATIONAL NORMS AND STANDARDS APPLICABLE TO SOVEREIGN DEBT WORKOUTS}

The most significant international standard specifically dealing with SODRs, given that most of the major international banks are members of the $\mathrm{IIF}^{34}$ and are creditors in sovereign debt transactions, is the IIF's Principles for Stable Capital Flows and Fair Debt Restructuring in Emerging Markets. ${ }^{35}$ This document seeks to establish SODR processes that are based on ". . . shared information, are conducted in good faith, and seek to achieve a fair outcome for all parties". ${ }^{36}$ It stipulates four principles that should guide the SODRtransparency and timely flow of information, close debtor-creditor dialogue and cooperation to avoid restructuring, good faith actions, and fair treatment. ${ }^{37}$ The IIF's elaboration on these principles states that the debtor should implement policies that promote macro-economic stability, sustainable growth and market confidence, that the SODR is a voluntary process of good faith negotiations that should respect the sanctity of contract, and that the debtor should avoid discriminating among its creditors. The IIF contends that a process based on its principles maximizes the likelihood that the debtor will regain market access "as soon as possible under sustainable macroeconomic conditions". ${ }^{38}$ It is important to note that the Principles include no reference to the responsibilities of the creditors to respect the human rights of the citizens of the debtor country. In fact, the Principles do not suggest that the creditors have any responsibility to take the likely impact of their actions on these citizens into account in their negotiating and decision making process.

Another applicable standard is UNCTAD's Principles on Responsible Borrowing and Lending. ${ }^{39}$ These principles seek to offer guidance to both sovereign borrowers and their creditors on how they can behave responsibly in both planning and implementing their financial transactions. They make clear that the sovereign debtor and its creditors share responsibility for ensuring that the sovereign's debts are sustainable. ${ }^{40}$ The UNCTAD Principles stipulate, inter alia, that the lender should recognize that the government officials involved in sovereign borrowing have a responsibility to protect the public interest; ${ }^{41}$ that the lender should make a realistic assessment of the borrower's capacity to service the loan based on the best available information and due diligence; ${ }^{42}$

34. According to the IIF's website, "[t]he Institute of International Finance is the global association of the financial industry, with close to 500 members from 70 countries." Available at: https://www.iif.com/about (last visited April 14, 2016).

35. Supra note 7.

36. Id., Principle 11.

37. Id.,13-16.

38. Id., 11 .

39. UNCTAD, supra note 8 .

40. Id., see Preamble at 4.

41. Id., Lender Principle 1.

42. Id., Lender Principle 4. 
and that any debt restructurings should be based on good faith and a cooperative spirit to reach a consensual arrangement as quickly as is feasible. ${ }^{43}$ The lenders also have a responsibility, in the specific context of project financing to conduct adequate social and environmental impact assessments that are proportional to the technical expertise of the lender and the size of the debt. $^{44}$

The UNCTAD Principles stipulate that sovereign borrowers have complimentary responsibilities. Thus, governments have a responsibility to protect the interests of their citizens in their financial transactions; ${ }^{45}$ they should honor their financial obligations; ${ }^{46}$ they should be transparent in their obligations, including to their own citizens; ${ }^{47}$ they should avoid over-borrowing and should manage their debts responsibly ${ }^{48}$ and debt restructurings should be undertaken promptly, efficiently and fairly. ${ }^{49}$ In the specific case of project finance, sovereign borrowers also have an obligation to undertake ex ante social and environmental impact assessments and should make their results public. ${ }^{50}$ It is interesting to note that these Principles do not explicitly make reference to either the human rights obligations of the sovereign borrower or to the human rights responsibilities of the lenders.

UNCTAD has also issued the Roadmap for sovereign debt workouts. ${ }^{51}$ It provides an overview of the shortcomings with the current SODR arrangements, a set of principles to guide SODRs, and recommendations on how the SODR process can be reformed. In its discussion of the short-comings with the current process it highlights the fragmented and uncoordinated nature of the current process, the fact that the process cannot guarantee a fair outcome for either the debtor or its creditors and that the process is inefficient and may result in an outcome that is "too little too late". It suggests furthermore that the process could be improved if it was based on a common set of principles. ${ }^{52}$ These would ensure that the process is legitimate, impartial, transparent, conducted in good faith, and aimed at producing a sustainable outcome. ${ }^{53}$ Importantly a sustainable outcome is defined as one that is based on a SODR process that is efficient, produces a debt situation that does not "lead to violations of economic or social rights or prevent the attainment of internationally agreed development goals". ${ }^{4}$ The Roadmap's concern with human rights is indicated in Section 4 of the document, which deals with restructuring terms and post-restructuring issues. In its discussion of its recommendations regarding sustainability, the Roadmap states that

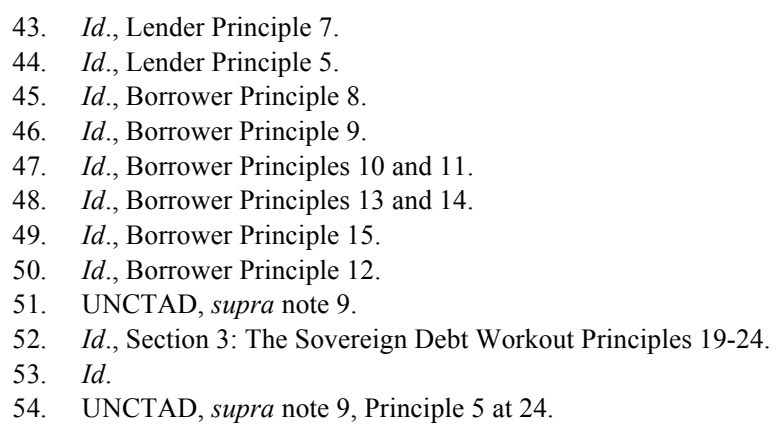


sustainability is a holistic concept and thus "requires going beyond merely economic considerations" and stipulates that "[r]espect for human rights, particularly socio-economic rights, and political risks need to be taken into account". ${ }^{55}$ In addition, the Roadmap, in its recommendations for dealing with uncooperative creditors, suggests that the debtor should not agree to any terms that would violate the "economic and social rights of citizens in the debtor state". 56

It is important to note that the Roadmap provides no guidance on how the parties should implement these recommendations on human rights. In addition, the Roadmap focuses on social and economic rights and does not specifically discuss civil, political and cultural rights. It also makes no specific reference to any international human rights treaties. This is noteworthy because the international instruments dealing with business and human rights make clear that the responsibilities of businesses extend to all human rights and are not limited to specific categories of rights. This observation is also applicable to SODRs which, like any business transaction, can implicate the full range of human rights. Finally, it should be noted that the Roadmap, even though it was issued in 2015, makes no reference to the UNGPs.

In 2011, the United Nations Human Rights Council endorsed the Guiding Principles on Foreign Debt and Human Rights (HRC Guiding Principles). ${ }^{57}$ These principles are designed to balance the contractual obligations of debtors and creditors arising from their external debt arrangements and their obligations to respect human rights. ${ }^{58}$ The HRC Guiding Principles establish foundational principles for dealing with foreign debt and human rights that include the following: ${ }^{59}$

- ensuring the primacy of human rights - all states have the obligation to respect, protect and fulfill the human rights of their populations and all private corporations have the responsibility to respect human rights;

- equality and non-discrimination - states have an obligation to design and implement policies and programs that promote a "more equitable and non-discriminatory distribution of benefits. . . 60 and should conduct impact analyses to promote this principle, particularly in regard to vulnerable groups in society; ${ }^{61}$

- progressive realization of rights - states are obliged to ensure that their external debt arrangements "do not hinder the progressive realization" of human rights and non-state lenders must ensure

55. UNCTAD, supra note 9 , at 54.

56. Id., at 59 .

57. U.N. Human Rights Council: Guiding principles on foreign debt and human rights, annexed to the Report of the Independent Expert on the effects of foreign debt and other related international financial obligations of States on the full enjoyment of all human rights, particularly economic, social and cultural rights, Cephas Lumina, U.N. Doc. A/HRC/20/23 (April 10, 2011).

58. Id., Section 1 paragraph 2.

59. Id., Section II.

60. Id., paragraph 12 .

61. Id., paragraphs 11-14. 
that their debt contracts with states respect human rights; ${ }^{62}$

- minimum core obligations - states must ensure that their external debt obligations do not derogate from their obligations to provide "minimum essential levels of economic social and cultural rights; ${ }^{63}$

- non-retrogression - states should ensure that their external debt repayment obligations do not lead to them adopting measures that impair advancements of economic social and cultural rights. ${ }^{64}$

The HRC Guiding Principles also include a set of operational principles, which require the state to conduct a participatory and transparent needs assessment before borrowing and suggest that the lenders should conduct due diligence to ensure that the loan to the state will be used for a public purpose and will not lead to unsustainable debt servicing obligations for the state. ${ }^{65}$ The principles also specify that the key terms of loan agreements should be publicly disclosed by both the borrower and the lenders ${ }^{66}$ and that the debtor state should ensure that its debt servicing obligations are not so burdensome that they cause the diversion of states resources away from the realization of human rights. $^{67}$ In regard to sovereign debtors in difficulty, the HRC Guiding Principles stipulate that, while the debtor state should honor its "legitimate" external debt obligations, ${ }^{68}$ it should renegotiate these obligations with the aim of reaching an agreement that "enables the debtor state to service its external debt without compromising its capacity to fulfill its international human rights obligations [...]". ${ }^{69}$

Two points should be noted about the HRC Guiding Principles. First, the HRC Guiding Principles deal explicitly with the human rights impacts of SODRs, as well as all other aspects of the human rights implications of external debt. Nevertheless, the HRC Guiding Principles are not specifically referred to in any of the other norms and standards relevant to SODRs discussed above. As will be seen below, they are also not specifically referenced in any of the human rights policies of the leading financial institutions, although many of them do make specific references to other relevant norms and standards in their human rights policies. ${ }^{70}$ Second, the HRC Guiding Principles, which were endorsed by the UN Human Rights Council less than a month after the endorsement of the UNGPs, are clearly influenced by them and their view of the responsibilities of corporations to respect human rights. ${ }^{71}$

Finally, the United Nations General Assembly (UNGA) has adopted

62. Id., paragraphs $15-16$.

63. Id., paragraph 18.

64. Id., paragraphs $19-20$

65. Id., paragraphs $36-41$.

66. Id., paragraph 43 .

67. Id., paragraphs 48-51.

68. Id., paragraph 52 .

69. Id., paragraph 53 . banks).

70. See infra notes 101-108 and accompanying text (discussion of human rights policies of

71. U.N. Human Rights Council, supra note 57, paragraph 9 and accompanying footnote. 
resolutions dealing with sovereign debt restructurings and the need for a more effective and balanced sovereign debt workout mechanism. In 2014, it adopted a resolution calling for the establishment of a multilateral legal framework for sovereign debt restructuring. ${ }^{72}$ The Resolution does not make specific reference to human rights. On the other hand, it does refer to the UNCTAD Principles on Responsible Sovereign Lending and Borrowing and on the need for the restructuring process to contribute to the fulfillment of the sustainable development goals and the progressive development and codification of international law. In 2015, the UNGA passed another resolution that sets out the basic principles for sovereign debt restructuring processes. ${ }^{73}$ The resolution includes recognition of the sovereign prerogative to make its own economic policies, and calls for the sovereign debt renegotiation process to be based on the principles of good faith, transparency, impartiality, equitable treatment, sovereign immunity, legitimacy, and sustainability. The resolution includes a definition of sustainability that states that the SODR outcome should preserve creditors' rights and promote "sustained and inclusive growth and sustainable development", minimize "economic and social costs", warrant the "stability of the international financial system" and respect "human rights". ${ }^{74}$

It should also be noted that the IMF has also issued many documents dealing with sovereign debt restructuring, including proposals for a sovereign debt restructuring mechanisms. ${ }^{75}$ However, these documents do not mention human rights as a factor for creditors and debtors to consider in their restructuring negotiations.

The common feature of all these documents is that they seek to establish processes for financial transactions, including debt workouts, with sovereign debtors that are transparent, based on good faith by both parties and will result in sustainable outcomes. In addition, the 2015 UNGA resolution includes principles relating to respect for the sovereignty of the debtor state, equitable treatment by the debtor of all its creditors, and creditor decisions by majority voting. The resolution includes a definition of sustainability that stipulates that the SODR outcome should preserve creditors' rights and promote "sustained and inclusive growth and sustainable development", minimize "economic and social costs, warrant the "stability of the international financial system" and respect "human rights". ${ }^{76}$ This definition of sustainability is similar to the one in the Roadmap, which states "Sustainability requires that sovereign debt workouts are completed in a timely and efficient manner and lead to a stable debt situation while minimizing costs for economic and social rights and development in the debtor state".

As indicated, only three of these documents mention human rights. They

72. G.A. Res. 68/304 (Sept. 17, 2014).

73. G.A. Res. $69 / 319$, supra note 26 .

74. Id., paragraph 8 .

75. Krueger, supra note 26: International Monetary Fund, A Survey of Experiences with Emerging Market Sovereign Debt Restructurings, IMFs Monetary and Capital Markets Department (June 5, 2012), available at http://www.imf.org/external/np/pp/eng/2012/060512.pdf.

76. G.A. Res. 69/319, supra note 26, paragraph 8. 
are the HRC Guiding Principles, the 2015 UNGA Resolution containing principles on the sovereign debt restructuring process and the UNCTAD Roadmap. ${ }^{77}$ Although, the HRC Guidelines have been endorsed by the UN Human Right Council, it is not clear if they have had any impact on the creditors. As indicated they have not been referred to in any of the other norms and standards dealing with SODRs or in any of the human rights policies of the major international financial institutions. There also does not appear to be any evidence that they have been expressly used by sovereign debtors in SODRs. The UNGA merely mentions human rights in its definition of sustainability. The third document was prepared by a group of experts and has not been formally endorsed by states. ${ }^{78}$ Moreover, the Roadmap, which only expressly mentions the need to respect social and economic rights, does not discuss human rights in any detail, and does not cross reference any human rights treaties or other human rights documents, such as the UNGPs.

\section{INTERNATIONAL NORMS AND STANDARDS DEALING WITH BUSINESS AND HUMAN RIGHTS}

The most detailed and authoritative international instrument dealing with business and human rights is the United Nations Guiding Principles on Business and Human Rights (UNGPs). ${ }^{79}$ It was endorsed by consensus by the United Nations Human Rights Council in 2011. Its "protect, respect and remedy" framework has been incorporated into a number of other international instruments dealing with the human rights responsibilities of particular types of businesses, for example multinational companies, in the OECD Guidelines on Multinational Enterprises (Guidelines). It also been incorporated into some standards dealing with particular types of business activities, for example the Voluntary Principles on Security and Human Rights, developed by the extractive industries in the US and the UK and interested civil society organizations, and applicable to the security practices in the extractive industry. The applicability of the UNGPs to financial institutions has been acknowledged, as indicated above, by various individual financial institutions ${ }^{80}$ as well as by groupings of financial institutions. ${ }^{81}$ In addition, it is the

77. It should be noted that in January 2015, the current U.N. Independent Expert on foreign debt and other related international financial obligations proposed 6 human rights benchmarks that should be taken into account in developing a multilateral framework for debt restructurings that build on the UNGPs and the UNCTAD Principles. However, these benchmarks have not yet been incorporated into any set of norms and standards applicable to SODRs by the Human Rights Council. See, Juan Pablo Bohoslavsky, Towards a Multilateral Legal Framework for Debt Restructuring: Six Human Rights Benchmarks States Should Consider (Jan 26, 2015), available at http://www.ohchr.org/Documents/Issues/Development/IEDebt/DebtRestructuring.pdf.

78. It should be noted that the Principles on Responsible Sovereign Lending and Borrowing have been specifically endorsed by some countries, namely Argentina, Brazil, Cameroon, Gabon, Germany, Honduras, Italy, Morocco, Nepal, Norway, Mauritania and Paraguay. See UNCTAD, Progress Report (2013), available at http://unctad.org/en/PublicationsLibrary/gdsddf2013misc2_en.pdf. 11.

79. UNITED NATIONS OFFICE OF THE HIGH COMMISSIONER FOR HUMAN RIGHTS, supra note

80. See statements by individual banks cited above, infra notes 103-108 and accompanying text.

81. See Thun Group of Banks, Discussion Paper for Banks on Implications of Principles 16(October 2013), available at http://business- 
international norm most relevant to the human rights impacts of SODRs because it deals with both the human rights obligations of the debtor state and the human rights responsibilities of the creditor financial institutions. It is discussed in more detail below.

The OECD Guidelines are the oldest general standard applicable to multinational enterprises (MNEs). It is important to note that they are intended to provide guidance from states to MNEs under their jurisdiction but are not binding on either the OECD member states or their MNEs. However, the states are expected to encourage the MNEs in their jurisdiction to comply with these Guidelines in their transnational operations. They are also expected to establish National Contact Points, to monitor the implementation of the Guidelines and to receive complaints about compliance with the Guidelines.

The Guidelines, which were originally developed in the 1970s, deal with all aspects of an enterprise's relations with its host governments. They are applicable to all $\mathrm{MNEs}^{82}$ and so are applicable to all financial institutions that operated transnationally. They have been revised a number of times. The most recent revision was in 2011, when a new section was added specifically to deal with human rights. The new section is based on the UNGPs and it closely tracks those provisions of the UNGPs dealing with the responsibilities of companies. In order to assist financial institutions to meet their obligations under the Guidelines, the OECD, in 2014 prepared a guidance note for the financial sector on due diligence. ${ }^{83}$ It is intended to help them determine their responsibilities for conducting due diligence in their operations and in their business relations so that they avoid causing, contributing to or being directly linked to adverse human rights impacts through these operations and relationships.

Another norm of general application to companies is the UN Global Compact. ${ }^{84}$ The Compact requires signatory companies to pledge that they will comply with ten principles, the first two of which deal with human rights. These two principles require signatory companies to "support and respect the protection of internationally proclaimed human rights" they are not complicit in human rights abuses". ${ }^{86}$ The four principles ${ }^{87}$ dealing with labor issues are also relevant to the human rights responsibilities of signatory companies. ${ }^{88}$ They require signatories to comply with international

\footnotetext{
humanrights.org/sites/default/files/media/documents/thun-group-discussion-paper-final-2-oct-2013.pdf; Equator Principles (June 4, 2013), available at http://www.equatorprinciples.com/resources/equator_principles_iii.pdf; Global Alliance for Banking on Values, Principles on Sustainable Banking (2009), available at http://www.gabv.org/about-us/our-principles.

82. OECD Guidelines, supra note 13, Article I paragraph 4.

83. OECD Global Forum on Responsible Business CONDUCT, Due Diligence In THE FINANCIAL SECTOR - ADVERSE IMPACTS DIRECTLY LINKED TO FINANCIAL SECTOR OPERATIONS, PRODUCTS OR SERVICES BY A BUSINESS RELATIONSHIP (2014), available at https://mneguidelines.oecd.org/globalforumonresponsiblebusinessconduct/GFRBC-2014-financialsector-document-1.pdf.

84. U.N. Global Compact, supra note 12.

85. Id., Principle 1.

86. Id., Principle 2.

87. Id., Principles 3-6.

88. A total of 8610 companies have signed onto the Global Compact; this includes 171 banks and

a total of 905 financial services companies. Information retrieved from
}


standards dealing with freedom of association and collective bargaining, forced labor, child labor and non-discrimination. It is important to note that the Compact is voluntary and signatories are only expected to submit information on how they are implementing the principles to the UN. There is no formal monitoring or evaluation of their compliance, although companies can be dropped from the list of signatory companies if they do not provide the requisite reports to the $\mathrm{UN}$. In addition, the principles are not very detailed and so provide significant room for interpretation.

The third norm of general application, ISO 26000, is issued by the International Organization of Standards (ISO) and deals with social responsibility. This norm is also voluntary and can be used by all companies. According to the ISO, ISO 26000 "is intended to provide organizations with guidance concerning social responsibility" ${ }^{89}$ The ISO does not certify that companies are in compliance with ISO 26000 and its website specifically states that the norm "is not intended to be interpreted as an "international standard", "guideline" or "recommendation" . . . Further, it is not intended to provide a basis for legal actions, complaints, defenses or other claims in any international, domestic or other proceeding". ${ }^{90}$ Nevertheless it has a detailed section on human rights that, like the UNGPs, deals with issues like due diligence and grievance mechanisms to address the potential human rights impacts of the operations and relationships of companies adopting ISO $26000 .^{91}$

In addition, to these norms and standards of general application there are some that are specifically applicable to the financial sector. The best known of these is the Equator Principles, ${ }^{92}$ which is designed to guide the conduct of banks engaged in project financing. It has been adopted by 83 financial institutions in 36 countries, ${ }^{93}$ all of which are expected to prepare annual reports on their implementation of the Equator Principles. The Principles are modeled on the IFC's Sustainability Framework, which provides guidance to the IFC and its clients on what the IFC expects in regard to assessing and monitoring the impact on sustainability of those projects that it funds. Both the IFC framework and the Equator Principles include provisions dealing with human rights, which, like the UNGPs, impose a responsibility on companies to assess the human rights impact of their activities. However, in both cases, this guidance is limited to the project financing context. Nevertheless, the Equator Principles can be seen as providing some sense of the standards of conduct expected from financial institutions when their operations have a significant impact on sustainability, including a significant human rights impact.

\footnotetext{
https://www.unglobalcompact.org/ (April 14, 2016).

89. See http://www.iso.org/iso/catalogue_detail?csnumber=42546 (April 14, 2016).

90. Id.

91. See ISO, DISCOVERING ISO 26000 (2014), available at http://www.iso.org/iso/discovering_iso_26000.pdf. Interestingly for a document that is expected to promote social responsibility, the ISO sells ISO 26000 for a price of CHF 198, which effectively makes it unaffordable to many potential stakeholders that may have an interest in understanding how the companies that may adopt ISO 26000 understand and implement their social responsibility.

92. Equator Principles, supra note 81.

93. Id.
} 
The one international standard that has been developed within the United Nations that is explicitly aimed at the financial sector is the United Nations Environmental Programme's Principles for Responsible Investment. ${ }^{94}$ Its six principles are designed to encourage institutional investors and commit signatories to pay greater attention to environmental, social and governance issues in their operations and business relations. There is no explicit mention of human rights in these principles. To date approximately 1500 asset managers, investment managers and professional service partners have signed onto these principles. ${ }^{95}$

\section{UNGPS}

The UNGPs, which were endorsed by consensus by the state members of the UN Human Rights Council, are applicable to all businesses, including financial institutions, and to all states. This non-binding instrument is based on the following three propositions: ${ }^{96}$

1) Under existing human rights law, states have an obligation to respect, protect and fulfill the human rights of their citizens.

2) Business enterprises have a responsibility to comply with all applicable law and to respect the human rights of those individuals that are impacted by their operations.

3) There need to be appropriate remedies available to all who are harmed by the failure of states and companies to live up to their respective obligations and responsibilities.

Based on these propositions, the UNGPs consist of thirty-one principles divided into three pillars. The first pillar, which consists of ten principles, focuses on the state duty to protect human rights. ${ }^{97}$ It stipulates that the state must protect against human rights being abused by third parties including business enterprises that are subject to its jurisdiction. In furtherance of this obligation, states must take steps to prevent human rights violations through their policies, legislation and regulations. They should also clearly set out their expectations of the business enterprises operating in their jurisdictions regarding human rights and, where appropriate, should encourage businesses to communicate how they address human rights impacts in their operations. They also have an obligation to promote respect for human rights by the business enterprises with which they conduct commercial transactions.

The second pillar, which consists of thirteen principles, deals with the responsibilities of business enterprises. ${ }^{98}$ It states that business enterprises should respect human rights, which means that they should avoid infringing human rights and should address the adverse human rights impacts in which they are involved. It also clarifies that for these purposes, "human rights"

94. United Nations Environmental Programme, Principles for Responsible Investment (2006), available at $\mathrm{http} / / \mathrm{www}$.unpri.org/about-pri/the-six-principles/.

95. See http://www.unpri.org/signatories/signatories/ (April 14, 2016).

96. U.N. Global Compact, supra note 11.

97. Id.

98. Id. 
means the rights expressed in the International Covenants on Civil and Political Rights and on Economic, Social and Cultural Rights and the principles set out in the ILO's Declaration on Fundamental Principles and Rights at Work. The principles also stipulate that businesses should have human rights policies that are approved at a high level in the company and are publicly available. The UNGPs also clearly state that the responsibility to respect human rights requires companies to avoid causing or contributing to adverse human rights impacts and to seek to mitigate or prevent adverse impacts that are directly linked to their operations. It further stipulates that companies should have in place due diligence procedures to identify, prevent, mitigate and account for the human rights impacts of their operations. This process should assess both actual and potential impacts that are caused by the company, to which the company contributes or which may be directly linked to its operations. The company should communicate how these impacts will be addressed and be monitored. It is important to note that these human rights impact studies differ from "standard" corporate due diligence procedures in that their focus is on the impact of the company's operations on its various stakeholders-workers, customers, communities - rather than on the potential risks to the company arising from the operations. Nevertheless, human rights impact assessments (HRIA) may be similar in methodology and may address some of the issues considered in a company's environmental, social and health impact assessments. In fact, in many cases, the company can consider incorporating the HRIA into its environmental and social impact assessment. ${ }^{99}$

The UNGPs make clear that the appropriate human rights due diligence process in any particular business situation will vary according to the size of the enterprise, the risk of severe human rights impacts and the nature and context of the operation. The nature of the enterprise's response to the identified adverse impacts will also vary according to the severity of the impact, the role that the enterprise plays in the adverse impact, and its leverage in addressing the adverse impact. The UNGPs also make clear that the responsibility of the company is ongoing and it is expected to continue monitoring the situation and to keep assessing the adverse impacts throughout the life of the transaction or operation. It is important to note that the fact that the due diligence is ongoing, indicates that the UNGPs contemplate that the human rights impacts of the project can vary over the life of the project or transaction and that the company should continue monitoring and dealing with the impacts as they evolve over the life of the project. Finally, the UNGPs acknowledge that the company may need to prioritize actions to address the actual and potential adverse human rights impacts of its operations and suggests that it should first seek to prevent and mitigate those impacts that are most severe or for which delayed responses may make them irremediable.

The third pillar deals with access to remedies. ${ }^{100}$ It stipulates that states, as part of their duty to protect against human rights abuses must take steps to

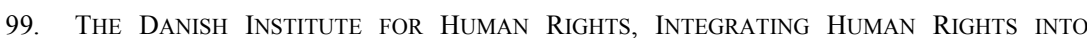

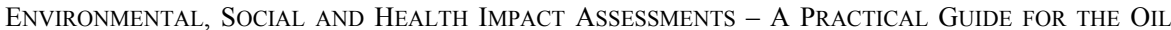
AND GAS INDUSTRY (2013); see also IPIECA, available at www.ipieca.org and www.humanrights.dk.

100. Equator Principles, supra note 81. 
ensure that those who are adversely affected by a business' operations should have access to either judicial or non-judicial remedies. The UNGPS also state that businesses, in order to ensure that grievances relating to adverse human rights impacts, are addressed as early as possible and can be remediated as directly as possible, should provide effective operational level grievance mechanisms. Finally, the UNGPs require that in order for non-judicial grievance mechanisms, including operational level mechanisms, to be considered effective they must be legitimate, accessible, predictable, equitable, transparent, rights compatible, and a source of continuous learning by the company. The Principles also suggest that these mechanisms should be based on engagement and dialogue with stakeholder groups.

It is clear from this brief description of the UNGPs, that there is no specific type of business or financial transaction to which they are not, at least in principle, applicable. In fact, a number of financial institutions have begun to express support for this view in their human rights policies, which are publicly available documents and in their public reports. ${ }^{101}$ For example, JP Morgan Chase \& Co. states in its human rights policy that ". . .we acknowledge the Guiding Principles on Business and Human Rights as the recognized framework for corporations to respect human rights in their own operations and through their business relationships." states that: "We aim to operate in accordance with the Universal Declaration of Human Rights as well as other international standards, including the Organisation for Economic Cooperation and Development's Guidelines for Multinational Enterprises and International Labour Organization Core Conventions." 103 Goldman Sachs, states in its policy that: "As a global financial institution, Goldman Sachs recognizes and takes seriously its responsibility to help protect, preserve and promote human rights around the world." ${ }^{104}$ HSBC states in its human rights policy that: "HSBC is guided by the International Bill of Human Rights and supports the UN Declaration of Human Rights and the principles concerning fundamental rights set out in the International Labour Organisation's Declaration on Fundamental Principles and Rights at Work. ... The UN Guiding Principles state that all private enterprises hold an equal responsibility to respect human rights. HSBC is committed to respecting human rights". ${ }^{105}$ Deutsche Bank states in its Corporate Responsibility Report for 2014 at p34: "We are committed to respecting human rights, in accordance with our values and beliefs . . . and as a signatory to the

101. It should be noted that not all banks have human rights policies or include human rights statements in their reports on sustainability and corporate social responsibility. For example leading Asian institutions such as Mizuho Bank Ltd., Mitsubishi UFJ Financial Group, and ICICI Bank Ltd do not have explicit human rights policies.

102. See https://www.jpmorganchase.com/corporate/About-JPMC/ab-human-rights.htm.

103. Barclays Group Statement on Human Rights 2015, available at https://www.home.barclays/content/dam/barclayspublic/docs/Citizenship/Policy-Positions/barclaysstatement-human-rights.pdf.

104. See Goldman Sachs statement on Human Rights, available at http://www.goldmansachs.com/investor-relations/corporate-governance/corporate-governancedocuments/human-rights-statement.pdf.

105. HSBC Statement on Human Rights 2015, available at http://www.hsbc.com/ /media/hsbc-com/citizenship/our-values/pdfs/150930-hsbc-statement-on-humanrights. 
UN Global Compact. Our policies and guidelines reflect our commitment to the UN Guiding Principles on Business and Human Rights."

Banks are not the only financial institutions to have stated that it is their policy to respect human rights in their operations. Insurance companies have made similar statements. For example, Allianz states in its 2014 Sustainability Report that:

[R]especting human rights is not just an issue for states and governments today. Companies from all industries have an increasing responsibility to incorporate human rights issues into their business standards, wherever and however they operate. ... Corporations are not only expected to take into consideration the human rights impacts directly caused by their own activities and operations, but also those linked to a business relationship with business partners. The latter makes the determination of the appropriate action more complex, as the link is only through the business relationship. Corporations must look at human rights not only from a business risk perspective, but also from the perspective of the people impacted, the "rights-holders.

In fact, of the 38 financial institutions represented on the Board of Trustees of the IIF, 30 have human rights policies that include similar statements to the ones cited above. ${ }^{108}$ All the institutions cited above except Barclays are represented on the IIF Board. Moreover, 21 of the 30 globally significant financial institutions (GSIFIs) have human rights policies that specifically refer to at least some of the applicable human rights norms and standards. In fact, eight GSIFIs specifically express support for the UNGPs in their human rights policies. ${ }^{109}$ Another GSIFI has a public statement that indicates that it accepts that it has human rights responsibilities but it does not expressly refer to any of the applicable human rights norms and standards and two other GSIFIs do not have human rights policies but have signed the UN Global Compact. ${ }^{110}$

106. See https://www.db.com/cr/en/positions/human_rights.htm.

107. See https://www.allianz.com/en/sustainability/sustainability_report_2014/special_topics /human_rights.html/.

108. The 30 financial institutions that have human rights policies are: HSBC, Credit Suisse AG, SEB, Akbank T.A.S, Swiss Re Ltd., Itaú Unibanco Holding S/A, Banco de Crédito del Perú, Erste Group Bank AG, Allianz SE, UBS AG, Commerzbank AG, Standard Chartered Bank, Grupo Santander, The Goldman Sachs Group, Inc., Citigroup, Deutsche Bank AG, Zurich Insurance Group, UniCredit Group, Aberdeen Asset Management, BBVA, Morgan Stanley, DBS Group Holdings and \& DBS Bank Ltd, ING Group, BNY Mellon, MetLife, Inc., Standard Bank Group Ltd, BNP Paribas, Société Générale, JPMorgan Chase, Scotiabank; the 8 financial institutions that do not have human rights policies are: Gulf international Bank, Qatar National Bank, Mizuho Bank Ltd., Mitsubishi UFJ Financial Group, ICICI Bank Ltd, Industrial and Commercial Bank of China, Sumitomo Mitsui Financial Group, Bank of China.

109. The eight GSIFIs that express support for the UNGPs in their human rights policy are Citigroup, Deutsche Bank, UniCredit, Credit Suisse, Nordea, Royal Bank of Scotland, Santander, and UBS.

110. Information is based on a review of the policies available on the websites of the GSIFIs, as defined by the Financial Stability Board. See http://www.fsb.org/wp-content/uploads/2015-update-oflist-of-global-systemically-important-banks-G-SIBs.pdf for list of GSIFIs. The 21 GSIFIs that have human rights policy are: HSBC, JP Morgan Chase, Barclays, BNP Paribas, Citigroup, Deutsche Bank AG, Bank of America, Credit Suisse, Goldman Sachs Inc., Morgan Stanley, Unicredit, BNY Mellon, Groupe BPCE, Group Credit Agricole, ING Group, Nordea, Royal Bank of Scotland, Société Générale, Standard Chartered Bank, UBS, Grupo Santander. The GSIFI, which has a public statement that indicates that it accepts that it has human rights responsibilities but does not expressly refer to any of the applicable human rights norms, is Wells Fargo. The two GSIFIs that do not indicate expressly state that they accept human rights responsibility but have signed the U.N. Global Compact are State Street and 
This suggests that, at least in theory, the UNGPs should be taken into account by the debtor state and its commercial creditors in a sovereign debt workout. The issue of what role, if any, the UNGPS should play in SODRs will be considered in the next section.

\section{THE ROLE OF THE UNGPS IN SODR ${ }^{111}$}

The issue of the potential role of the UNGPs in SODRs can be divided into three sub-issues: First, should the UNGPs be part of the framework that helps guide SODRs? Second, can the UNGPs add value to SODRs? Third, what do the UNGPs suggest that the debtor and creditors should do in regard to assessing and preventing or mitigating adverse human rights impacts in SODRs? Each question will be discussed in turn, below.

\section{A. The Role of the UNGPs in the SODR Framework}

First, I will address the question of whether the UNGPs should be part of the framework that helps guide transactions in SODRs. As indicated above, the UNGPs are applicable to all businesses in all their operations and business relations. This suggests that the UNGPs, at least in theory, should be applicable to SODRs in the case of states that have commercial institutions as creditors. ${ }^{112}$ This supposition is strengthened by the fact that the UNGPs do not include any language indicating that there are exceptions to their applicability to all businesses and their activities.

It is, of course, also true that the UNGPs are non-binding. This means that, in principle, both the sovereign debtor and its creditors are free to decide not to utilize the UNGPs in their SODRs. However, for both parties such a decision does not necessarily mean that they have no human rights responsibilities in conducting an SODR. The reason is that the sovereign debtor is bound, under international law, by the human rights treaties that it has signed and ratified and by customary international law. ${ }^{113}$ This means, since all states have signed at least some treaties, and most states have signed the two core

Industrial and Commercial Bank of China Limited. The six GSIFIs that do not have a human rights policy or any statement referring to any human rights norms and standards are: Mitsibushi UFG FG, Agricultural Bank of China, Bank of China, China Construction Bank, Mizuho FG, Sumitomo Mitsui FG.

111. It is important to note that the U.N. Principles on Foreign Debt and Human Rights are also applicable to SODRs. They are not directly discussed in this section for two reasons. First, as indicated above, they are based, in part, on the UNGPs. Thus, they impose similar responsibilities on both debtors and creditors as the UNGPs. Second, the Principles do not seem to have gained any influence with financial institutions. For example, they have not been referred to in any of the human rights policies of individual financial institutions reviewed for this paper.

112. The UNGPs apply to businesses. Consequently, they would only be applicable to commercial creditors of sovereign debtors. This means that the discussion in this section is unlikely to be relevant to low income sovereign debtors who only have official bilateral and multilateral institutions as creditors.

113. See John Humphrey, The Universal Declaration of Human Rights: Its History, Impact and Judicial Character, in HUMAN Right: THIRTY YEARS AFTER THE UNIVERSAL DECLARATION (Bertrand G. Ramcharan ed., 1984); Final Act of the Conference on Security and Co-Operation in Europe, The Helsinki Accord, 14 ILM 293 (1975); Hurst Hannum, The Status of the Universal Declaration of Human Rights in National and International Law, 25 GA. J. INT’L \& COMP. L. 287 (1995). 
international human rights covenants ${ }^{114}$ - the Covenants on Civil and Political Rights $^{115}$ and on Economic, Social and Cultural Rights ${ }^{116}$ - that all sovereign debtor states have some binding human rights obligations. At a minimum, therefore, each debtor state, ${ }^{117}$ in a SODR process, will be required to respect, protect and fulfill the rights enshrined in the human rights treaties it has signed or that are binding under customary international law, regardless of its views of the applicability of the UNGPs to the process. This means, inter alia, it has an obligation to protect the rights of its citizens from any adverse human rights impacts they may suffer that are caused by third parties, such as businesses operating in their territory or that are directly linked to these businesses or to which these businesses are contributing.

The situation of the creditors is more complicated. They are not signatories of any of the human rights treaties and, since they are not subjects of international law, are not directly bound by customary international law. Consequently, they do not have any explicit human rights obligations under international law. However, they are obliged to comply with the law in the states in which they operate. This suggests that, to the extent that these states have incorporated their international human rights treaties into domestic law, these companies will be required to respect the international human rights commitments of their home and host states. In addition, the companies may have assumed at least a moral commitment to respect human rights to the extent they have adopted their own individual human rights policies or have signed onto one or more of the applicable international standards dealing with human rights and businesses. ${ }^{118}$ As indicated above, a number of leading financial institutions have adopted human rights policies in which they expressly acknowledge that they have human rights responsibilities, and that these responsibilities are based on core international human rights instruments. ${ }^{119}$ Some of them have also expressed support for the non-binding international standards. These institutions have not indicated that their human rights policies are not applicable to any specific category of their activities.

114. There are 168 state parties to ICCPR as of 18 March 2016. Seven states have signed but not ratified treaty, 22 states neither signed nor ratified treaty. There are 164 state parties to ICESCR as of 18 March 2016, six states have signed but not ratified treaty, 25 states neither signed nor ratified treaty. Information retrieved from http://indicators.ohchr.org/.

115. International Covenant on Civil and Political Rights (1966) entered into force on 23 March 1976, G.A. Res. 21/2200A (XXI), available at http://www.ohchr.org/Documents/ProfessionalInterest /ccpr.pdf.

116. International Covenant on Economic, Social and Cultural Rights (1966), entered into force 3 January 1976, G.A. Res. 21/2200A (XXI), 993 UNTS 3, available at http://www.ohchr.org/Documents/ProfessionalInterest/cescr.pdf.

117. It should be noted that the home state of the creditor institutions may also have some extraterritorial human rights obligations, including to ensure that their creditor institutions respect the human rights of the populations of the debtor state. See Maastricht Principles on Extra-Territorial Obligations of States in the Area of Economic Social and Cultural Rights (2013) available at http://www.etoconsortium.org/nc/en/mainnavigation/library/maastrichtprinciples/?tx_drblob_pi1\%5Bdown loadUid\%5D=23 (last visited April 14, 2016).

118. In the case of the financial sector, the relevant international standards are the UNGPs, Global Compact, Equator Principles, UNEP Principles on Responsible Investing, Thun Group statement, OECD Guidelines.

119. See examples supra notes 101-110 (dealing with IIF members and GSIFIs that have human rights policies). 
Consequently, there is no principled basis on which they can claim that either their own human rights policies or those international standards for which they have expressed support are not applicable to SODRs. The failure to apply them without an adequate explanation, therefore, should result at least in reputational costs to these financial institutions. It may also, at least at the margins, provide the debtor with some bargaining leverage in their negotiations with these financial institutions.

The conclusion to be drawn from the above is that the obligations and responsibilities set out in the UNGPs do apply to SODRs, at least in regard to the sovereign debtor and to those creditors that have voluntarily accepted the responsibilities of the UNGPs and have not expressly excluded SODRs from this responsibility.

\section{B. The Value-Add of UNGPS}

The second question that the parties must consider is whether the UNGPs can add value to their efforts to restructure the sovereign's debts. There are several reasons for thinking that the UNGPs can add value to these difficult negotiations.

First, as shown above, it is almost inevitable that SODRs will have adverse human rights impacts. This follows from the fact that the debtor does not have sufficient funds to meet all its obligations to both its creditors and its citizens. Consequently, it will have to deprive some of these stakeholders of resources-financing, goods and services - that they are expecting. These decisions of the debtor will have human rights consequences at least to the extent that they affect expenditures on such items as health, education, social services, the justice system, and unemployment compensation. There may also be human rights impacts if the debtor's policies generate significant public opposition. The UNGPs, by providing guidance to states on how they should account for the human rights impacts arising from their financial transactions, can assist the sovereign debtor in ensuring that it adequately accounts for the actual and potential adverse human rights impacts in the planning, negotiation and implementation of its SODR.

Second, as indicated above, many of the globally significant financial institutions, which are likely to be participants in many SODRs, have publicly acknowledged that they do have human rights responsibilities. Moreover, a number of the leading financial institutions have specifically expressed their support for the UNGPs in their human rights policies. It should be noted that these institutions have not explicitly stated whether or not their human rights policies apply to SODRs. In the absence of such a statement and given that their policies appear to be applicable to all the activities of the institutions, there does not seem any a priori reason to assume that their policies are not applicable to SODRs. The UNGPs, by providing guidance to financial institutions on how they should implement their responsibility to respect human rights can assist the creditors to understand how to structure SODR outcomes that avoid or mitigate the adverse human rights effects of their SODR proposals and of the eventual agreements that they reach with their sovereign debtors. 
Third, the UNGPs, with their emphasis on due diligence and access to remedies, remind the debtor and its creditors that they will need to take all stakeholders who may suffer adverse impacts into account in their transaction. This is useful because, at least in principle, they will ensure that there are no interests on either the borrower or the lender side that are not taken into account in the planning and execution of the SODR. This means that the interests of those debtor country citizens who are adversely affected by the budgetary allocation decisions of the sovereign debtor should receive due consideration. In addition, it means that the interests of relevant creditor stakeholders, such as pensioners who are bondholders ${ }^{120}$ who may be adversely by the SODR outcome, should be taken into account.

Fourth, history suggests that SODRs that do not pay adequate attention to the adverse human rights and other impacts of their outcomes may not be fully implemented and may need to be renegotiated. This can happen because, inter alia, the debtor is unable to implement the agreement as planned due to the opposition of domestic stakeholders or because the financial markets lack confidence in the viability of the outcome and so do not participate as anticipated in it. These developments may force the parties to renegotiate the restructuring, possibly under more difficult financial and more contentious negotiating conditions and at considerable expense to the parties. The net effect of these developments is likely to be that the adverse human rights impacts of the SODR outcome will also be exacerbated. The UNGPs can help the parties mitigate the risk of such a situation by making sure that they pay appropriate attention to human rights considerations in their first round of SODR negotiations.

It should be noted that incorporating the UNGPs into the SODR also has a cost. This follows from the fact that the UNGPs add a new requirement onto the SODR process. They require the parties to incorporate human rights considerations, as determined through a human rights impact assessment, into the SODR process. As will be discussed below, performing an adequate human rights impact assessment under the time pressures of a sovereign debt crisis and in the context in which the outcome of the SODR is hard to predict ex ante is challenging. Inevitably the assessment will be imperfect and is likely to expose the creditors to reputational risk. This follows from the probability that the SODR will result in substantial adverse impacts for at least some segments of the debtor country population and from the fact that the sovereign debtor has a strong incentive to blame the creditors for the adverse impacts of the SODR.

However, it is important to recognize that the creditors are likely to incur this cost regardless of whether it follows the UNGPs and conducts the requisite human rights impact assessment or not. The reason is that if, in fact, there are adverse impacts, the debtor and its adversely affected citizens will have a strong incentive to blame the creditors for them. Showing that they are complying with the UNGPs may help the creditors mitigate these risks. The reason is that they can show that they have taken human rights considerations bonds.

120. This was the case with some of Argentina's creditors and with the holders of Puerto Rican 
into account and that they have done so in conformity with the best applicable international standard. In addition, their human rights impact assessments might help demonstrate that they have worked to reach the least costly and most feasible, in human rights terms, SODRs agreements.

The above suggests that on balance the benefits of incorporating the UNGPs into the SODR outweigh the costs. The reason is that the benefits flow directly from the UNGPs and cannot easily be earned from a substitute approach. The costs arise from the specific context of a sovereign debt crisis and, to that extent, are unavoidable. However, the UNGPs may help the parties mitigate the consequences of these costs.

\section{Debtors, Creditors and Human Rights in SODRs}

In order to answer the third question-what the UNGPs suggest that the debtor and creditors should do in regard to human rights in SODRs - each of the three pillars of the UNGPs will be discussed separately.

\section{The First Pillar: Duties of the Sovereign Debtor}

As indicated above, the state, under international human rights law has a duty to protect, respect and fulfill the human rights of its citizens. This duty includes the duty to protect its citizens against human rights violations by business enterprises.

This means that the state has a general duty to protect its citizens against adverse human rights impacts that are caused by financial institutions, to which financial institutions contribute or which are directly linked to financial institutions. This duty includes protecting its citizens against the adverse human rights impacts that flow from financial transactions between the state and financial institutions. In other words, the state, in the context of SODR has two duties. It must ensure that its own actions comply with its duty to protect, respect and fulfill the human rights of its citizens. In addition, it has a duty to protect its citizens against the adverse human rights impacts that may arise from or be connected to the conduct of its creditors in its financial transactions.

In regard to its own actions, in order to ensure that it is not failing to comply with its own human rights obligations, the state needs to determine the nature of the adverse impacts of its proposed course of action in the SODR. In particular, it needs to consider if these actions will merely result in slower realization of some or all of its subjects' rights than would otherwise have happened or if it will result in an actual deterioration in some or all of the human rights of its subjects over the same period. Armed with this knowledge the sovereign debtor will have to determine what it can do to prevent or mitigate the adverse impacts. To the extent this is not possible, at least over the relevant time period for the transaction, it will have to decide what it can do to compensate those adversely affected for their losses. It is important to note that this obligation, if fully complied with, requires the state to make an assessment of how the individual adverse impacts will evolve over the life of the SODR transaction and also how the various human rights impacts will interact with each other over the relevant time period. It will also have to consider whether 
either these individual or cumulative impacts will continue beyond the term of the SODR. This assessment may also result in the state having to make some decisions on whether it is acceptable to impose the adverse impacts on the present generation of citizens with the expectation that doing so will generate benefits for future generations.

The state's obligation to protect its citizens against human rights violations by its creditor counterparts means that it should not agree to a transaction that causes avoidable adverse impacts on the human rights of its citizens. ${ }^{121}$ This does not necessarily mean that the state cannot agree to any SODR that has adverse human rights consequences, particularly when the exigencies of the situation leading to the SODR are taken into account. However, it does mean that the state needs to understand the human rights impacts of the offers made to it by the creditors and to assess whether these impacts can be avoided or mitigated if the offer is accepted and implemented. In order to make a fully informed decision in this regard, the debtor should be aware of the human rights policies of the financial institutions with which it is doing business so that it can understand if their offers are consistent with these policies and, if not, why the financial institutions are deviating from their own policies. Finally, the debtor state needs to engage in discussions with the creditors about the most effective way to mitigate the adverse human rights impacts of their transaction within the context of the SODR. In this regard, the sovereign debtor needs to make sure that its creditors understand the debtor's human rights obligations and how it thinks they should apply in the context of the SODR.

Within the context of SODRs, the state's obligation to protect needs to include some plan for either restoring the ex ante human rights situation by the end of the SODR implementation period or for compensating those adversely affected for their losses. This requires the state to assess the evolution of both the impacts of the SODR transaction and the steps taken to mitigate the adverse impacts over time. It will also have to determine what to do in the event that its projections about the evolution of these impacts turns out to be inaccurate and the human rights situation turns out to be different from what it anticipated.

This brief description of the state's obligations suggests the most effective way to gain this insight, at least in theory, is for the state to do a careful human rights impact assessment of the likely human rights consequences of the SODR. As indicated in the UNGPs, although in the

121. See Committee on Economic, Social and Cultural Rights, General Comment 3, The nature of States parties' obligations (Fifth session, 1990), U.N. Doc. E/1991/23, annex III at 86 (Dec 14, 1990), reprinted in Compilation of General Comments and General Recommendations Adopted by Human Rights Treaty Bodies, U.N. Doc. HRI/GEN/1/Rev.6 at 14 (May 27, 2003). Paragraph 10 of this Comment stipulates that states have "a minimum core obligation to ensure the satisfaction of, at the very least, minimum essential levels of each of the rights...it must be noted that any assessment as to whether a State has discharged its minimum core obligation must also take account of resource constraints applying within the country concerned. In order for a State party to be able to attribute its failure to meet at least its minimum core obligations to a lack of available resources it must demonstrate that every effort has been made to use all resources that are at its disposition in an effort to satisfy, as a matter of priority, those minimum obligations." Paragraph 11 of the Comment adds that "...even where the available resources are demonstrably inadequate, the obligation remains for a State party to strive to ensure the widest possible enjoyment of the relevant rights under the prevailing circumstances." 
context of the responsibilities of business, such due diligence is not a one-off requirement. Instead the state should continue monitoring and assessing the situation on an ongoing basis throughout the life of the transaction. This suggests that the state has an obligation to perform the HRIA in advance of its decision to enter into the SODR and to continue updating it through the negotiations with its creditors and then throughout the implementation of the agreement reached in the SODR. ${ }^{122}$

There are two important considerations that the state will need to take into account in undertaking the HRIA. The first is that the advent of a debt crisis can happen quickly and can demand a prompt response. Thus, the HRIA must be done under considerable time pressure that is exacerbated by the fact that the process leading to the decision to enter into the SODR must be managed with discretion. If the news that the sovereign debtor is contemplating entering into a SODR leaks prematurely it can adversely affect the financial situation of the state, and thereby exacerbate the human rights consequences of the SODR.

This suggests that the HRIA in the case of SODR is unlikely to comply with best practice standards of transparency and participation and detailed analysis in regard to such impact studies. ${ }^{123}$ This also means that there is a heightened risk of unexpected adverse human rights outcomes once the SODR is being implemented. This, in turn, underscores the importance of the debtor creating a grievance mechanism, a topic to which we will return when discussing the third pillar of the UNGPs.

The second issue, as discussed above, is that a SODR almost inevitably will require the state to make budget cuts. ${ }^{124}$ The supposed justification for these cuts, which all SODR participants understand will cause pain and adverse human rights impacts, is that the society must accept some short term costs, in order to restore a sustainable macro-economic situation and to position itself on a sustainable growth path. This in turn is expected to generate future human rights gains. Assuming that this justification is correct, it amounts to concluding that it is acceptable to impose current human rights sacrifices in order to reap future human rights gains. It is unclear how human rights law should assess this inter-temporal human rights trade-off. Although, at a minimum it should comply with the requirements that retrogressive measures should be non-discriminatory, proportionate and should comply with the states minimum core obligations. ${ }^{125}$ Evaluating this trade-off is further complicated by

122. In this regard it is interesting to note that the European Commission has done a social impact assessment of the stability support programme for Greece. See European Commission, Assessment of the Social Impact of the new Stability Support Programme for Greece, Commission Staff Working Document, SWD(2015) 162 final (Aug 19, 2015).

123. It is interesting to note that Iceland made an effort to understand the human rights impacts of its proposed SODR during its 2008 banking crisis. See Report of the Independent Expert on the effects of foreign debt and other related international financial obligations of States on the full enjoyment of all human rights, particularly economic, social and cultural rights on his mission to Greece, U.N. Doc. A/HRC/31/60/Add.2 (Feb 29, 2016).

124. The extent of these cuts will be influenced by its ability to identify new sources of financial support. Many debtor states will obtain such support from the IMF and multilateral development banks.

125. See General Comment 3 of the Committee on Economic Social and Cultural Rights, supra note 118; Goldmann, supra note 18. 
the fact that the current human rights costs can be assessed with reasonable certainty but the future human rights benefits are uncertain and their scope and scale depend on the assumptions made about the likely future trajectory of the SODR and its impacts. In addition, the identity of the current losers can be determined with a reasonable degree of confidence but the identity of the future winners is less easily established. Moreover, there is no necessary reason to assume that the future gainers will be the current losers. This is particularly relevant because in the context of SODRs, human rights impacts in fact are likely to be cumulative, that is, for example, current cuts in education spending can have adverse impacts on the future health of the adversely affected learners and can have negative impacts on their job prospects. There is no obvious reason to assume that these currently adversely affected learners will benefit from future increases in education spending.

\section{The Second Pillar: The Responsibility of Financial Institutions}

The UNGPs stipulate that business enterprises have a responsibility to respect the human rights of those actually or potentially affected by their operations or business relations. It clarifies that the core of this obligation is for the business enterprise to engage in sufficient due diligence to identify the human rights impacts of its planned operations and to take steps to prevent or mitigate the adverse impacts.

This standard suggests that the creditor financial institutions have a responsibility to undertake a HRIA before engaging with the sovereign debtor about the SODR. In addition, they should continue updating the HRIA during the SODR negotiations, and when it is concluded and is being implemented. As in the case of the sovereign debtor, the financial institutions are expected to undertake this HRIA under considerable time constraints and in conditions in which complying with high standards of detailed analysis, transparency and participation will be difficult if not impossible. Furthermore, as in the case of the sovereign, this situation places a premium on the need for providing those adversely affected by the SODR with access to remedies.

It is clear from the literature on HRIAs that they are still a relatively new form of impact assessment and that practitioners are still working out the best way to do such assessments. ${ }^{126}$ Nevertheless, there are certain characteristics that should feature in any HRIA that complies with the UNGPs. Each of these is discussed below together with the issues they raise in the context of SODRs.

It is well understood that in all impact assessments it is necessary to have a sense of the human rights conditions that exist before the parties enter into their transaction or operation. In principle, this should not be a problem

126. ISO 26000 supra note 14; Danish Institute for Human Rights, supra note 99; Oxfam Technical Briefing, A Oxfam Perspective on the UN Guiding Principles (2013), available at https://www.oxfam.org/sites/www.oxfam.org/files/tb-business-human-rights-oxfam-perspective-un-

guiding-principles-130613-en.pdf; Oxfam \& FIDH, Community-Based Human Rights Impact Assessment: The Getting it Right Tool (2011), available at https://www.fidh.org/IMG/pdf/cobhra training manual.pdf; DANISH INSTITUTE FOR HUMAN RIGHTS, HUMAN RIGHTS IMPACT ASSESSMENT - GUIDANCE AND TOOLBOX (2016), available at http://www.humanrights.dk/sites/humanrights.dk/files/media/dokumenter/business/hria_toolbox/hria_gu idance_and_toolbox_final_feb2016.pdf. 
because, pursuant to the UNGPs, the financial institutions and the sovereign borrower should have done HRIAs before they entered into their original debt transactions and they should be monitoring the impacts over the life of the transaction. In this case, they would have a good sense of the existing human rights situation before commencing the SODR. However, in reality, at least while the HRIAs requirement is still relatively new, it is unlikely that the parties have done HRIAs for all their financial transactions.

Even if the creditors had done HRIAs of their individual transactions with the borrower, it is unlikely that they would have gathered information on the cumulative impacts of all the debtor's financial transactions. This is because they may not have been involved in all the transactions and so would not have done, $a b$ initio, studies indicating how the impacts of the various transactions interact with each other, either to reduce or increase over time the adverse human rights impacts. Thus, they are unlikely to be in a position on their own to make a truly informed judgement about the likely human rights impacts of the SODR. If one looks at cases of recent SODRs, such as Greece, ${ }^{127}$ it is clear that the cumulative impacts of these multiple agreements can be substantial. In addition, it is clear that understanding them is a pre-condition for assessing the likely impacts of an SODR. This suggests that there will be a need for the creditors and the debtor to cooperate in undertaking the SODR HRIA.

In the event that the parties do not have a good baseline study, they will be confronted with a complicated human rights challenge. Both parties will know that they are undertaking a transaction that is likely to adversely impact the human rights of at least some of the debtor's subjects but without a clear understanding of the scope and scale of the impacts or how they may interact with each other. They may also not have the information to determine which of the possible SODR outcomes would be the least harmful option for all the affected stakeholders. Moreover, they will lack the time to undertake the kinds of studies that might help them understand the impacts. The net effect is that they will enter into the SODR with imperfect knowledge about the human rights implications of their proposed actions and in conditions in which they cannot easily take the public into their confidences about the proposed transaction.

The conclusion to be drawn from this situation is not that it is too difficult to apply the UNGPs to SODR. Rather, it is that the UNGPs need to be applied pragmatically. The parties should do the best HRIA that is feasible under the circumstances, understanding that they are unlikely to meet HRIA best practice standards.

The situation is further complicated by the fact that the outcome of the SODR will be a negotiated solution that will depend to a large extent on the negotiating dynamics and the balance of bargaining power between the state and its creditors. This means that neither the state nor the creditors can fully assess the impacts of the SODR before an agreement is concluded. They will not be able to determine, with any degree of confidence the full range, scale or

127. Truth Committee on Greek Public Debt, supra note 2; Salomon \& De Schutter, supra note 
scope of all the impacts until they have a clear understanding of how much the debtor will have to pay, over what period and subject to what conditions. Consequently, their initial ex ante assessments will be more in the nature of a list of likely human rights impacts, without detailed information on the scale of the impact. This assessment will need to be adjusted as their negotiations proceed toward the final deal. The factors that will influence their assessment of the human rights impact of the SODR outcome include the size of the budget cuts the debtor will have to make, over what period, what external support may be available to help deal with these cuts, how this may change over time, and what measures the adversely affected stakeholders can take to counter the effects of the cuts. This information will also allow them to more confidently assess the trajectory of the adverse human rights impacts over time.

It is important to note that the HRIA needs to evaluate the impact of any proposed SODR on all relevant stakeholders and to assess whether the overall impact of the transaction on all these stakeholders is the least harmful from a human rights perspective. This suggests that there will be some situations where the financial institutions are contemplating transactions that may have irreconcilable, in human rights terms, impacts. For example if they pay too much attention to those adversely affected in the debtor country and take too generous steps to prevent or mitigate their harm, they may end up unduly impacting the interests of some bondholders, such as pensioners that count on the interest they earn as holders of the debtor's bonds for their monthly income. This suggests that, at least in some cases, SODR is a zero-sum game and that in making their HRIA assessments, the financial institutions will need to assess how this game evolves over the life of the SODR.

Needless to say, the parties' assessment of these outcomes over this period will depend on the assumptions they make about the relative severity of the impacts on the different stakeholders, and the reactions of the affected persons. In addition, their estimate of the human rights impacts will be affected by their assumption about the time period over which the impacts will manifest themselves. If they assume too short a time horizon they may over-estimate certain adverse human rights impacts which manifest themselves immediately after the SODR is concluded and may under-estimate certain mitigating factors relating to these impacts that manifest themselves more slowly. Conversely they may under-estimate the actual adverse impacts if they do not allow sufficient time to assess how the adverse impacts interact with each other and to determine their cumulative impacts. This means that certain possible SODR outcomes could be seen as being more or less desirable depending on the time horizon used in the impact assessment.

These issues and the complexities of applying the first two pillars of the UNGPs in the context of SODR, underscores the importance of the third pillar for dealing with the grievances that are likely to arise in the context of the implementation of the SODR.

\section{The Third Pillar: Access to Remedies}

As indicated above, there are substantial constraints on the ability of both the state and the creditors to undertake effective due diligence in advance of 
agreeing a SODR. Consequently, there is a strong likelihood that there will be stakeholders whose interests have not been adequately accounted for in the HRIA of the outcome of the SODR. According to the UNGPs they should be given access to either judicial or non-judicial forums in which they can seek a remedy for this situation. ${ }^{128}$ Clearly in many cases, these stakeholders may, in principle, be able to bring their grievance to a judicial or administrative forum either in the debtor state or in one of the home states of the creditors. However, this can be expensive, time consuming and the result can be uncertain. Consequently, it is not clear if, in all cases, judicial forums will be able to offer adequate effective relief to all those stakeholders whose human rights have been adversely affected by the SODR.

This suggests that in many SODRs there will be a need for aggrieved parties to have access to some form of SODR-specific grievance mechanism. The UNGPs stipulates that these mechanisms should be legitimate, accessible, predictable, equitable, transparent, rights compatible, and a source of continuous learning by the company. ${ }^{129}$ The UNGPs also suggest that in setting up the mechanism, the parties should consult affected stakeholders on its performance and design. ${ }^{130}$ Subject to these criteria, the parties are free to design and operate a grievance mechanism that best suits their purposes.

A SODR-specific grievance mechanism offers the sovereign debtor and its creditors three benefits. First, it provides the parties with a relatively flexible, informal and independent third party dispute settlement forum. Thus, an aggrieved party, provided they meet its access requirements, can use the mechanism to have their claim for a remedy for the human rights harm caused by the SODR addressed by someone other than the debtor or the creditor. If the process is transparent and participatory, it should give claimants confidence that their claims have been fairly addressed and thus enable them to accept even an unfavorable outcome of the grievance mechanism procedure. This fact should also help boost public confidence in the responsiveness of the debtor and the creditors to the interests of all stakeholders in the SODR. This can help build support for the agreement amongst all stakeholders, thereby building confidence in the ability of the parties to implement the agreement.

Second, this is a mechanism for dealing with the unintended adverse human rights impacts of the SODR. Since these agreements will have been concluded under time pressure and in the context of a crisis, there is a probability that the parties to it will not take account of all relevant stakeholder interests. As a result, there is a reasonable chance that the agreement will have some unintended but adverse human rights impacts on some stakeholders. An operational level grievance mechanism offers these stakeholders a means for informing the debtor and creditor about these impacts before they become too severe. It also provides a way for the affected parties and the debtor and creditors to have a relatively independent third party deal with them on their merits. This can help reduce the risk that the unaddressed concern becomes

128. Id.

129. Principle 31, UNGPs, supra note 11.

130. Id. 
politicized and a potential threat to the overall efficacy of the agreement.

Third, a grievance mechanism, as indicated in the UNGPs, can perform a useful lessons learned function. The reason is that the mechanism generates empirical data about the actual impacts of SODR agreements and about how they can most effectively be managed. This may be of greater benefit to the creditors, many of whom are likely to have to deal with SODRs in the future, than to the sovereign debtor-who no doubt hopes not to have to repeat the SODR experience.

The benefits of the grievance mechanism are offset by two costs. First, the mechanism costs money to establish and maintain. An additional possible cost can arise if the grievance mechanism can provide compensation to parties that have been particularly severely affected by the SODR.

The question is who should be responsible for providing these funds - the debtor or the creditor? The answer to this question can have human rights implications. For example, if the debtor has to contribute the funds, it will have to cut its budget somewhere else, which may lead to such adverse impacts as job losses, reduced access to health care, education or social security for some citizens or reduced access to the justice system. On the other hand, if the creditor provides the funds, it might provide less debt relief to the debtor, which could also result in adverse human rights impacts.

Given, as indicated above, that the mechanism provides benefits to both the debtor and the creditor, it seems reasonable to expect both parties to contribute to the cost of the grievance mechanism. This would also have the benefit of enhancing the impression that the mechanism is impartial and independent.

A second potential challenge is that the mechanism could be overwhelmed, if individuals are allowed to bring complaints to the mechanism. This concern can be addressed through the jurisdictional requirements for the mechanism. For example, it could require cases to be brought by groups of individuals or organizations representing groups of individuals who have all been adversely affected in the same way. Such a requirement would also help the mechanism identify the most substantial and urgent complaints, thereby assisting it in allocating its time and resources efficiently and in optimizing its positive human rights impact on the SODR transaction.

The above discussion suggests that, on balance, the grievance mechanism offers more advantages than disadvantages to the SODR. This impression follows from the fact that the downsides of the mechanism, while not insignificant, can be effectively managed by the debtor and the creditors. Moreover, as the discussion of Pillars 1 and 2 of the UNGPs shows, there is a substantial risk that neither the creditors nor the debtor will be able to fully meet their/its responsibilities or obligations under the relevant pillar of the UNGPs in the context of a sovereign debt crisis. Consequently, they will benefit from having an independent, channel through which qualifying grievances can be addressed efficiently and fairly. 


\section{SODRS AND GLOBAL GOVERNANCE ${ }^{131}$}

The above discussion suggests that there are gaps in global economic governance relating to SODRs. The problem is not just that there is not a third party mechanism for coordinating and enforcing sovereign debt workouts. It is also that different aspects of the sovereign debt issue are being dealt with in different parts of the institutional architecture of global economic governance and they are not communicating effectively with each other.

Thus, the procedural issues of SODR are being deal with on an ad hoc basis and in arrangements established by the parties. "Procedural" in this context refers to the arrangements for the negotiations between the debtor and creditors in an SODR. It includes such issues as the sharing of information and how the parties should conduct themselves in these negotiations. It does not include "substantive" issues such as the principles that should guide the parties in deciding how to share the costs and benefits of the SODR among all the stakeholders in the negotiation, and how to account to those stakeholders who are adversely affected by the SODR for how they have been affected by the SODR. As this article indicates, the IIF and UNCTAD have developed some standards that seek to establish some principles to guide the SODR process. ${ }^{132}$ However, they focus on procedural concerns and do not deal in any detail with the substantive issues that are likely to arise in SODRs.

The substantive issues that can arise in SODRs can be divided into two categories. The first category consists of the economic and financial issues that need to be addressed in order to reach a sustainable outcome. These are usually dealt with by the parties through negotiation, although the IMF and possibly some of the multilateral development banks may play a role in facilitating agreement on these issues. At times, other international institutions may play a role. For example, the Bank for International Settlement has provided support in a number of SODRs, ${ }^{133}$ and the European Commission and the European Central Bank have played a role in the SODRs of Greece, Portugal, Ireland and Spain. $^{134}$

The second category consists of the social and political, including human rights, issues that arise in SODRs that will influence the sustainability of the SODR outcomes. Formally these issues are considered to be the prerogative of the sovereign debtor. This means that the sovereign is responsible for making the difficult choices about how to allocate, inter alia, the human rights costs of the SODR. However, as indicated above, de facto, it is untenable to maintain that the creditors and international financial institutions such as the IMF do not play a role in these allocative decisions. Moreover, in general terms, the

131. It is clear that this is a complex topic that cannot be discussed in any great detail in this paper. Consequently, this section will focus on how to promote a more integrated and holistic approach to the development of international standards applicable to the economic, financial, human rights, social and political aspects of SODRs and not on such global governance challenges as the creation of a sovereign debt restructuring mechanism.

132. Supra notes 7 and 8 .

133. Ugo Panizza, Federico Sturzenegger \& Jeromin Zettelmeyer, The Economics and Law of Sovereign Debt and Default, 47 JOURNAL OF ECONOMIC LITERATURE 651 (2009).

134. Philip R. Lane, The European Sovereign Debt Crisis, 26 THE JOURnAL of ECONOMIC PERSPECTIVES 49 (2012); Gianviti et al., supra note 18. 
international community through such instruments as the UNGPs, the Global Compact and the OECD Guidelines has made clear that it thinks that businesses, including financial institutions, have a responsibility to deal with the human rights impacts of their operations. Nevertheless, in no case, to date, has any sovereign debtor or its creditors expressly applied the international standards applicable to business and human rights to a SODR, despite the fact that some of the debtor states ${ }^{135}$ have endorsed the UNGPs and some of their creditors have expressly acknowledged their human rights responsibilities.

The fact that these procedural and substantive standards appear to run in parallel and appear not to intersect is problematic. ${ }^{136}$ At the level of the individual debtor state, sovereign debt crises are experienced holistically by the debtor country and its citizens. However, the fact that the international standards like the IIF Principles are taken into consideration by the creditors while international standards like the UNGPs are excluded from the SODR negotiations means that the human rights aspects of the crisis are unlikely to receive the same consideration as the economic and financial factors. The result is an over-emphasis on economic and financial considerations and an underestimation of the human rights and other social impacts, to the detriment of the overall efficacy and sustainability of the SODR. ${ }^{137}$

This situation is a symptom of a coordination gap in global governance arrangements that allows these two strands of thinking about financial interactions to operate in parallel rather than in communication with each other. It is possible that this deficiency could be corrected if all states could agree on one entity to which to delegate the responsibility to coordinate the development of international standards dealing with economics and finance issues and social, human rights and cultural matters. Such coordination would ensure that all these factors are taken into account in processes, such as SODRs, that are ultimately holistic in nature and are experienced as such by their stakeholders. While this may result in a SODR process that is more complicated and in negotiations between the debtor and creditor that are more difficult, it should also ultimately result in outcomes that are more sustainable and seen as more legitimate by all stakeholders.

The existence of this gap is intriguing given that the international community recognized the need for coordination between economic and social, including human rights, issues when it established the United Nations. The Economic and Social Council (ECOSOC) was expected to play this coordinating role. ${ }^{138}$ Unfortunately, time has demonstrated that the ECOSOC

135. The UNGPs were endorsed by consensus by all the member states of the U.N. Human Rights Council in 2011. For a list of the participating states, see http://www.ohchr.org/EN/HRBodies/HRC/Pages/Year20102011.aspx.

136. The one exception to this observation is the UNGA resolution on sovereign debt restructuring, see supra note 26 . However, it is too early to know if this resolution will have any impact on SODRs. In addition, the principles are set out in very general terms which may make them difficult to apply in a uniform way in different SODRs. Furthermore, history suggests that neither debtors nor creditors look to the UNGA for guidance when engaged in SODRs.

137. Concern about the dangers of paying inadequate attention to the social and human rights implications of SODRs was raised in Greece. See Truth Committee on Greek Public Debt, supra note 5; ECtHR, Koufaki and Adedy v. Greece, supra note 5, para. 47.

138. U.N. Charter, Chapter X (Articles 61-72) (Oct 24, 1945), 59 Stat. 1031, T.S. 993, 
has not been effective in playing this role. ${ }^{139}$ In addition, in the SODR context, the participants in the coordinating mechanism cannot be limited, like the ECOSOC, to states. As this article has shown, non-state actors, such as financial institutions are necessary participants in SODRs and thus will need to have access to any coordinating mechanism, if it is to be effective. Consequently there is a need for a new coordinating mechanism that can assist all relevant stakeholders in SODRs in ensuring that all the applicable international standards are integrated into the SODR process. Given the general complexities of SODRs and the lack of agreement on the need for an independent third party mechanism capable of enforcing a SODR outcome, and the range of considerations that should be taken into account in an SODR, it is unlikely that agreement could be reached on establishing a coordinating mechanism that has anything more than advisory powers. Nevertheless such an advisory mechanism if it had sufficient expertise and credibility and a sufficiently high profile, could play a useful informational role and could shift the burden of justifying exclusion of either the procedural or the substantive standards from an SODR onto those parties that are resistant to including both sets of standards.

\section{CONCLUSION}

SODRs are complicated transactions. They involve multiple actors with conflicting interests and agendas, sophisticated contractual arrangements; multiple regulatory environments, complex economic, financial and political contexts, and they need to be negotiated under time pressure. They usually must be concluded in the glare of publicity even though there are limitations on how transparent they can actually be if they are to be concluded relatively promptly and effectively.

The sovereign debtor and its creditors, in addition to dealing with all these factors, need to respond to the demands of at least some of the stakeholders in the SODRs that their outcomes comply with the evolving international norms dealing with the human rights responsibilities of businesses and the international legal obligations of sovereign debtors in this regard. The UNGPs offer the parties to the SODR, at least in those cases in which commercial creditors are involved, a basis for showing that they are responding to these demands and the applicable norms and standards. In practice this requires the parties to undertake appropriate due diligence, usually in the form of ex ante human rights impact assessments. However, as indicated above, in the specific context of SODRs there is not sufficient time or possibly the resources to fully apply the UNGP requirements, particularly in regard to due diligence. This means that both parties will have to do as much due diligence as is feasible under the circumstances. As a result, they will have to base their decisions on partial knowledge both about current human rights conditions and

available at http://www.un.org/en/sections/un-charter/chapter-x/; Goldmann, supra note 18; Sabine Michalowski, Sovereign Debt and Social Rights-Legal Reflections on a Difficult Relationship, 8 HuM. RTS. L. REV. 35 (2008).

139. Arguably the U.N. General Assembly is attempting to play this coordinating role in its 2015 resolution on sovereign debt principles. See supra note 26. 
the likely impact of the SODR on these conditions and the trajectory of these impacts over the life of the SODR. Applying the UNGPs, will help the parties deal with the risks arising from this situation by making sure that they are aware of the human rights impacts of their proposed transaction. In addition, their ability to manage these impacts will be enhanced if they implement the UNGPs requirement to establish an SODR-specific grievance mechanism. This mechanism can address complaints arising from the SODR that the parties may not have anticipated and that cannot adequately be dealt with in the applicable judicial and administrative forums.

There are three conclusions that follow from this complicated situation. First, the fact that the international standards dealing with business and human rights are not expressly taken into account in SODRs is problematic. It increases the risk of the debtor and creditors agreeing a SODR outcome that over-emphasizes economic and financial considerations and under-emphasizes the human rights and other impacts of the SODR. This in turn increases the risk that the SODR outcome will be sub-optimal and possibly distorted. This in turn risks undermining the legitimacy and sustainability of the SODR.

Second, the application of the UNGPs to the context of SODR highlights an important challenge for human rights laws. It shows that the way in which human right issues arise in the context of specific business transactions pose new conceptual challenges for human rights law. For example, it is not clear that human rights law can give the parties adequate guidance in working out if or under what conditions it is acceptable, from a human rights perspective, for them to accept short term adverse human rights consequences for inherently uncertain long term benefits. Human rights law may also not be able to assist them to determine how far they should stretch the lines of causation in assessing the cumulative impacts of the SODR. For example, if the SODR is shown to have an adverse effect on access to education, should the human rights impact assessment consider the likely consequences of the reduced access to education on the future employment, health, social welfare and other rights of the children who lose access to education and their families? Human rights law may also not be able to guide them in assessing how to balance the competing claims of different stakeholders in a SODR. For example, it may not be able to guide the creditors in deciding if they should attach greater priority to the adverse impacts on the people who lose their jobs in the debtor country because of the SODR, the people who lose access to health care because of cuts in the health budget in the debtor country or the individual bondholders in a second country who relied on the representations of the debtor country to purchase its debt and now could lose part of their life savings or have their monthly incomes cut if the debtor receives debt relief.

This conclusion makes clear that while the norms and standards in regard to business and human rights are well established in the sense that there is general consensus that businesses have human rights responsibilities, we are still only in the early stages of developing our knowledge about how human rights should be applied to businesses and how they should go about fulfilling their human rights responsibilities. We are also only beginning to learn how states should help businesses fulfill these responsibilities and how this will 
affect the human rights obligations of states. These are all issues that are in need of further research.

The third conclusion relates to global economic governance. This article suggests that there is a cost to be paid for treating the various international standards applicable to the process of SODR in isolation from the standards applicable to the substantive issues that arise in SODR, such as human rights impacts. These different standards need to interact with each and their application in specific contexts need to be coordinated to ensure that they operate in a mutually supportive fashion. This suggests that there is a need for an independent coordinating mechanism that can promote more effective coordination between the actors developing these two parallel strands of international norms and standards. Determining the precise nature, powers and make up of this mechanism requires further research. 